\title{
Mouse Models of Testicular Germ Cell Tumors
}

\author{
Delphine Carouge and Joseph H. Nadeau \\ Institute for Systems Biology \\ Seattle, Washington \\ USA
}

\section{Introduction}

Germ cell tumors arise from anomalies in primordial germ cells (PGCs) (Stevens, 1967), the embryonic precursors of oocytes and sperm. Their normal development follows three steps: migration, proliferation and differentiation into mature germ cells (Mauduit et al., 1999). Abnormalities in these steps can result in sterility, reduced fertility, or in some cases to transformation into ovarian tumors in females or testicular germ cell tumors (TGCTs) in males (Stevens, 1967), both of which present remarkable cellular and tissue heterogeneity reflecting the pluripotent nature of the TGCT stem cell.

Although representing only $1-2 \%$ of all cancers in men, TGCTs are the most common malignancy affecting young men 15-35 years of age (Buetow, 1995). Over the past decade, TGCT incidence has risen $\sim 1.2 \%$ per year with about $8,300-8,400$ new cases reported in the United States (American Cancer Society, www.cancer.org). TGCT risk varies more than 5fold among ethnic groups and geographic regions (McGlynn et al., 2005; www.cancer.org). In addition, developmental anomalies such as undescended testis are indicators of TGCT risk (Dieckmann \& Pichlmeier, 2004). Finally, environmental factors such as pesticides or insecticides strongly influence susceptibility. However, the mechanisms by which genetic and environmental factors affect susceptibility remain elusive.

Genetic factors account for $25 \%$ of susceptibility to TGCTs, making these tumors the third most heritable cancer (Gilbert et al., 2011). Family history is a significant risk factor with 8to 10-fold risk for brothers of men with TGCTs and 4- to 6-fold risk for sons (Hutter et al., 1967). The risk increases 75-fold for monozygotic twins (Swerdlow et al., 1999). Genomewide association studies (GWAS) in humans reveal various loci that contribute to susceptibility, but the identity of these genes has not yet been established (Gilbert et al., 2011). Discovery of TGCTs in the 129 family of inbred strains of mice has enabled identification and characterization of specific genes and their interactions (Stevens \& Little, 1954; Stevens, 1973).

In this chapter, after discussing the various mouse models for TGCTs, we review the evidence for TGCT genes and their role in tumorigenesis in both humans and mice. We consider the consequence of their mutation, as well as the role of gene interactions, to better understand molecular pathways of PGC transformation and pathogenesis. Finally, we discuss evidence for transgenerational effects that influence TGCT incidence. 


\section{Mouse models for human TGCTs}

Studies of TGCT development before birth are not feasible in humans. Laboratory mice therefore provide unique opportunities to determine the genetic basis for TGCT susceptibility and for characterizing key components contributing to PGC transformation.

\subsection{TGCT predisposition in the 129 inbred strain}

During gastrulation in the mouse embryo, PGCs arise from the ectoderm and the precursors of Leydig and Sertoli cells arise from the coelomic epithelium (Clark \& Eddy, 1975; Karl \& Capel, 1998). At 8 days post-coitum (E8), 50-100 PGCs are evident at the base of the allantois where they begin to be highly mobile (Fig. 1) (Clark \& Eddy, 1975; Molyneaux et al., 2001). From E9.5 onwards, PGCs rapidly exit the hind-gut epithelium and migrate toward the genital ridges (Molyneaux et al., 2001). During migration, PGCs proliferate reaching a maximum of 20,000-25,000 cells at E13.5 (Mauduit et al., 1999). Then, in males, PGCs become quiescent (mitotic arrest) and are called gonocytes (Mauduit et al., 1999). Pre-Sertoli cells appear in male gonads around E11 for playing roles in: (1) sex determination because of their SRY factor released (Albrecht \& Eicher, 2001); (2) migration of PGCs depending on chemotactic factors (i.e. KITLG, a specific-Sertoli factor) and germ-Sertoli interactions (Griswold, 1995); and (3) the arrest of male germ cell mitosis in G1/S phase (Karl \& Capel, 1998). Mitotic arrest is maintained until three days after the birth (P3) (Mauduit et al., 1999).

At P6, gonocytes differentiate into Type A1 spermatogonia and begin radial migration in the seminiferous tubule (Nagano et al., 2000). Germ cells undergo either a proliferative period (to maintain the progenitor population throughout the reproductive life of males) or meiosis (to mature germ cells) (Nagano et al., 2000). During these postnatal days, pre-Sertoli cells transform into mature Sertoli cells that support germ cell differentiation and spermatogenesis (Griswold, 1995; Hess et al., 2006). Remarkably, a significant proportion of PGCs remains scattered along the migratory route. These ectopic PGCs are eliminated between E10 and E17 by activating the intrinsic cell death pathway (Stallock et al., 2003). This intrinsic pathway is regulated by BCL2 family members (i.e. BAX, BAK and BCL2), which activate mitochondria leading to secretion of cytochrome $\mathrm{C}$, an initiator of apoptosis (Shimizu et al., 1999; Stallock et al., 2003). Another BAX-dependent apoptotic control point occurs at P10-P13 before meiosis to eliminate germ cells that fail either to migrate in the seminiferous tubules or to repair DNA (de Rooij, 2001).

In the 129 family of inbred strains, 5\%-10\% of males develop spontaneous TGCTs (Fig. 1) (Stevens \& Little, 1954; Stevens, 1967), making these strains highly relevant for learning about TGCT development in humans. Indeed, TGCTs in mice are most similar to pediatric TGCTs in humans, and both species have a similar left-sided preference of the tumors. Bilateral TGCTs are infrequent in mice and usually involve less than $5 \%$ of all cases in humans (Dieckmann \& Pichlmeier, 2004). The critical period for transformation is between E11.5-E13.5 in mice (Stevens \& Little, 1954; Stevens, 1967). Interestingly, syncytial masses of atypical gonocytes are detected in embryonic testis cords from E13 onward in 129 wild-type and mutant males (Stevens, 1967; T. Noguchi \& M. Noguchi, 1985; Rivers \& Hamilton, 1986; Matin et al., 1999). These atypical cells may result from incomplete cell cycle, mitotic arrest defects, or de-differentiation after their entrance in quiescence (Rivers \& Hamilton, 1986). 
These so-called embryonal carcinoma (EC) cells escape necrosis, and then proliferate and aggregate together to form clusters, which are correlated with partial or complete germ cell deficiency (Stevens, 1967; T. Noguchi \& M. Noguchi, 1985; Rivers \& Hamilton, 1986; Matin et al., 1999). Furthermore, EC clusters have been suggested as the precursors of either testicular abnormalities, which have been found in an appreciable frequency (18\%) in 129 males, or TGCTs (Rivers \& Hamilton, 1986). Similar abnormalities, termed carcinoma in situ, have been found in humans many years before invasive malignancy (Skakkebaek, 1972). Why some germ cells transform into EC clusters while others develop normally is unclear, just as why some abnormal gonocytes die while others persist.

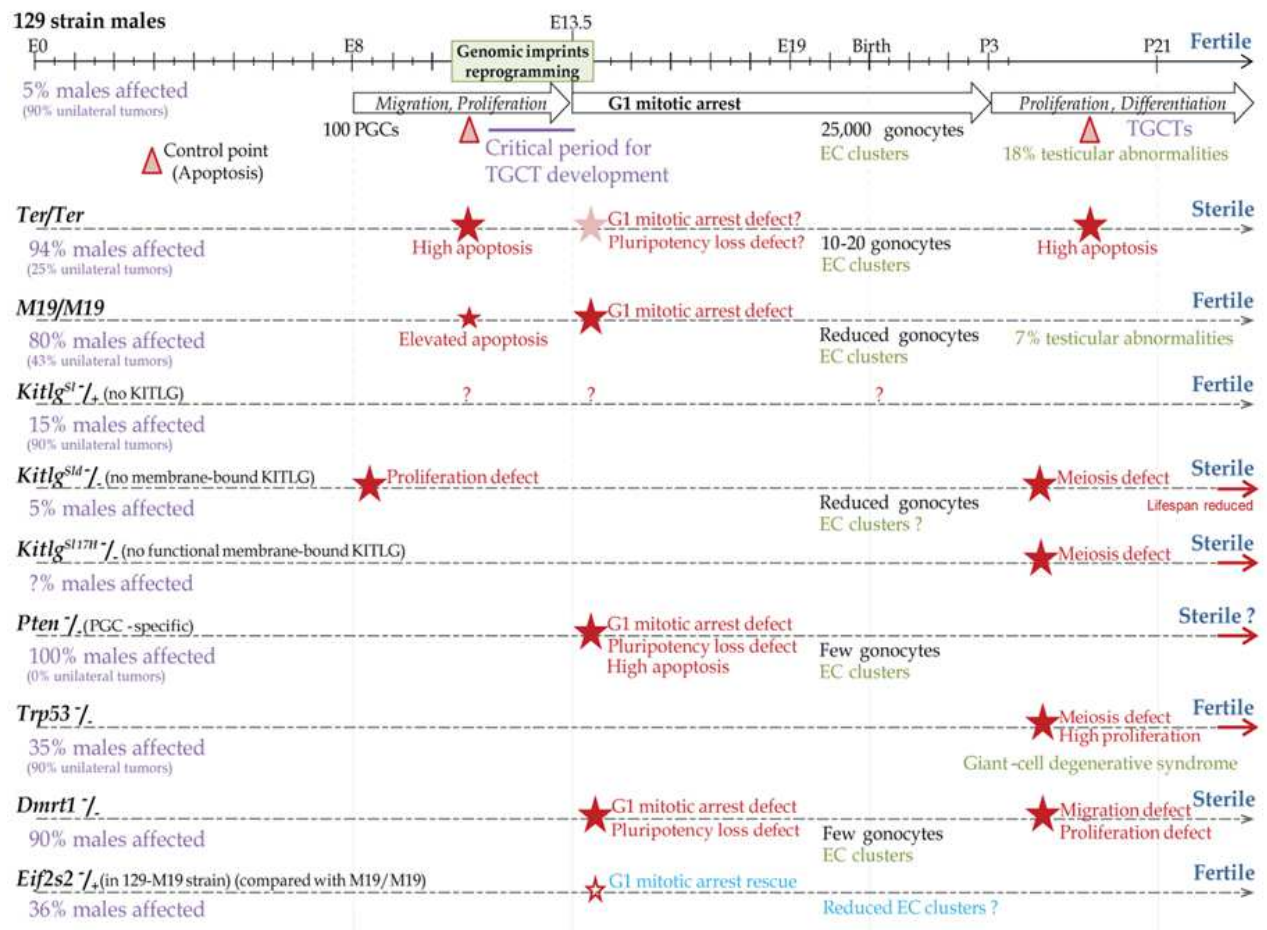

Fig. 1. Male germ cell development in mouse models for TGCTs in the 129 strain.

\subsection{TGCTs in the 129-Ter strain}

The Ter allele, also known as Teratoma, has dramatic effects on PGC biology and TGCT susceptibility (Stevens, 1973; T. Noguchi \& M. Noguchi, 1985), and was recently identified as a spontaneous mutation in the Dead-end (Dnd1) gene (Youngren et al., 2005). Ter homozygosity causes severe germ cell deficiency in both sexes, probably mediated through BAX-dependent apoptosis after E8.5 (Stevens, 1973; T. Noguchi \& M. Noguchi, 1985; Cook et al., 2009). EC clusters develop from E13 in 129-Ter/Ter male embryos probably due to a defect in G1/S mitotic arrest (Rivers \& Hamilton, 1986). The few surviving PGCs successfully migrate to the genital ridges, suggesting that DND1 is not essential for 
migration (Youngren et al., 2005). Deficiency progresses with age until P11 when PGCs are no longer detectable (T. Noguchi \& M. Noguchi, 1985; Cook et al., 2009). As a result, adult mutant males are sterile (Fig. 1) (T. Noguchi \& M. Noguchi, 1985). Somatic development of Sertoli and Leydig progenitors is not affected in accordance with the PGC-specific expression of Dnd1 (Weidinger et al., 2003). Interestingly, 17\% of 129-Ter/+ males develop tumors, $10 \%$ of which are bilateral, but these males are fertile. This rate increases to $94 \%$ in homozygotes with 75\% of cases having bilateral tumors (T. Noguchi \& M. Noguchi, 1985).

DND1 was originally proposed to be a component of the cytidine to uridine RNA editing complex given its similarity with the Apobec complementation factor (A1CF) (Weidinger et al., 2003). More recently, DND1 was shown to block miRNA access to their mRNA targets (Kedde et al., 2007). The reactivated target genes are involved in PGC pluripotency (i.e. Sox2, Nanos1 and Nanog), in cell cycle regulation (i.e. Cyclin-dependent kinase inhibitors (Cdkn) $1 b$, Cdkn1a) and in PGC survival (i.e. Transformation related protein (Trp53), apoptotic factor Bax and Phosphatase and tensin homolog (Pten)) (Kedde et al., 2007; Cook et al., 2011; R. Zhu et al., 2011). Dnd1 is expressed throughout embryogenesis with an up-regulation between E12.5 and E15.5 in males, the critical period for TGCT development (Youngren et al., 2005; Cook et al., 2009). Thus, loss of DND1 in Ter mutants strongly affects differentiation, survival and entry in quiescence of PGCs and dramatically enhances the TGCT frequency in the 129 strain.

\subsection{Consomic 129 inbred strains}

Chromosome Substitution Strains (CSSs, consomic strains) carry entire chromosomes derived from another inbred strain. Some CSSs were created to study the genetic linkage of the MOLF-derived TGCT modifier genes. MOLF is derived from Mus musculus molossinus, which is genetically distinct from 129 and has no predisposition for TGCTs (Mieno et al., 1989; Matin et al., 1998). We will review results for two consomic strains.

\subsubsection{9-M18}

The 129-M18 CSS substitutes MOLF-derived chromosome 18 for its homologue in 129 wildtype mice (Anderson et al., 2009a). 129-M18 males show complete resistance to develop TGCTs with no homozygous males affected. Four quantitative trait loci (QTLs, Region I-IV) were identified independent of the Dnd1 gene, which is also located on this chromosome.

Region I shows homology with the 10p11 region in humans (Copeland et al., 1993). One candidate gene may be Map3k8, which encodes a mitogen-activated protein kinase (MAPK) that acts downstream of tyrosine kinase-dependent pathway (Patriotis et al., 1994). Region II belongs to a conserved region $5 \mathrm{q}$ in humans (Copeland et al., 1993). In mice, this region contains Eif1a gene, which encodes a translational regulator that is functionally related to eIF2a, encoded by Eif2s2 gene, loss of which suppresses TGCT development (Heaney et al., 2009) (Section 3.5). However, the three homologues of Eif1a gene are EIF1AD on chromosome 11, and EIF1AX and EIF1AY on sex chromosomes in humans. Region III contains at least one TGCT enhancer and is conserved with the 18q region in humans (Copeland et al., 1993). An interesting candidate gene is Noxa, which encodes a mitochondria-mediated apoptotic factor (Krishna et al., 2011). Interestingly, Noxa is activated by the TGCT suppressor TRP53 (Michalak et al., 2005; Donehower et al., 1992) 
(Section 3.3). Region IV contains the F-box only protein 15 gene, one of the few known targets of the stem cell pluripotent factor OCT3/4 (Tokuzawa et al., 2003).

\subsubsection{9-M19}

The 129-M19 CSS substitutes MOLF-derived chromosome 19 for its homolog in 129 wildtype mice (Matin et al., 1999). Surprisingly, $80 \%$ of the homosomic males develop TGCTs and this unusually high tumor frequency remain elevated $(20 \%)$ when only one copy of M19 is present $(129-\mathrm{M} 19 /+)$ compared with 129 wild-type mice $(5 \%)$, suggesting a semidominant effect of the MOLF susceptibility locus (Matin et al., 1999; Youngren et al., 2003). In contrast with the 129-Ter strain, M19 does not cause complete germ cell deficiency (Fig. 1). Indeed, some PGCs can develop normally leading to fertility in both homozygous and heterozygous males. Furthermore, the incidence of bilateral tumors in 129-M19/M19 is reduced $(57 \%)$ compared with the 129-Ter strain $(75 \%)$ and are non-existent in heterozygous males (similar than in 129 wild type males) (Matin et al., 1999; Youngren et al., 2003). Thus, the phenotype of this consomic M19 strain is less severe than in the 129-Ter strain.

Regions on chromosome 19 are homologous to either 9p, which contains the TGCT modifier doublesex- E Mab3-related transcription factor 1 (Dmrt1) gene (Section 3.4), 9q, 10q, which contains the TGCT modifier Pten (Section 3.2) and 11q in humans (Copeland et al., 1993). An interesting candidate gene is Splicing factor 1 (Sf1), which encodes an RNA binding protein that functions as a pre-mRNA splicing factor (Z. Liu et al., 2001). Interestingly, Sf1 deficiency (heterozygous Sf1-/+) in 129-M19/+ males reduces the incidence of TGCTs (R. Zhu et al., 2010), suggesting that Sf1 may be one of the TGCT enhancer genes on chromosome 19 . D19Bwg1357e is a predicted gene down-regulated in the gonads of MOLF strain mice (R. Zhu et al., 2007). This gene has an RNA-binding domain homologous to those in Pum1 and Pum2 genes, which encode two major components of P-bodies, the center of RNA processing (Moore et al., 2003), suggesting a similar role for D19Bwg1357e.

Thus, CSSs are powerful tools for identifying new genes that, alone or in combination and with conventional additive or epistatic effects, confer susceptibility to TGCTs. These candidate genes are involved in RNA biology, epigenetic regulation and intracellular pathways regulating PGC survival, proliferation and pluripotency.

\section{TGCT modifier genes in the $\mathbf{1 2 9}$ strain}

Spontaneous and engineered mutations are essential for characterizing molecular pathways involved in PGC development and transformation into TGCTs. In this section, we review the phenotypic traits of 129 mice that carry mutations on TGCT modifier genes.

\subsection{Kit and Kitlg}

In the mouse, mutations at the White-spotting (W) or Steel (Sl) loci cause sterility and severe anemia that lead to in utero or perinatal death in homozygotes (McCoshen \& McCallion, 1975; Nocka et al., 1990). The $W$ locus, located on chromosome 5 in mice (region 4q12 in humans), encodes KIT, a tyrosine kinase receptor (Manova et al., 1990). The ligand of KIT, named KITLG, is encoded at the $S l$ locus on chromosome 10 in mice (region 12q21 in 
humans) (Flanagan et al., 1991). These two factors are essential for hematopoiesis, melanogenesis and gametogenesis (Bernstein et al., 1991; Besmer et al., 1993).

In the testis, KIT is expressed on the surface of PGCs from E7.5 to E13.5, and then at P5, on differentiating germ cells and interstitial Leydig cells (Manova et al., 1990; Yoshinaga et al., 1991). KITLG is only expressed by the pre-Sertoli and Sertoli cells (Rossi et al., 1991; Tajima et al., 1991). The two forms of KITLG, soluble and membrane-bound, are differentially expressed depending on developmental stages (Matsui et al., 1990; Flanagan et al., 1991; E.J. Huang et al., 1992). The membrane-bound KITLG is predominantly expressed during proliferative periods: between E8 and E14 and just after the birth (P3), and the soluble form when PGCs are quiescent (between E13.5 and P3) (Matsui et al., 1990; Flanagan et al., 1991; E.J. Huang et al., 1992). In addition of their essential role during migration, the interaction of KITLG with its receptor leads to the dimerization of KIT and its auto-phosphorylation activates two major pathways: (1) the PI3K/AKT signaling cascade regulates transcription of mitotic inhibitors such as CDKN1a, CDKN1b and cyclin D1, and enhances the translational factor eIF4E; (2) the MAPK pathway regulates factors involved in pluripotency such as NANOG and SOX2, and in proliferation (Mithraprabhu \& Loveland, 2009). By acting on TRP53 activity, KIT/KITLG pathway controls apoptosis of PGCs by regulating the BCL2 components (i.e. BAX, BAK, BCL2) and their cofactors (i.e. PUMA, NOXA) (Pesce et al., 1993; Carson et al., 1994), explaining why ectopic PGCs that lose KIT/KITLG interaction in 129 wild-type mice are eliminated by apoptosis.

Loss of KIT (KitW and KitWv) or KITLG (KitlgSl, KitlgSll and Kitlgslgb) leads to massive PGC loss, resulting from high levels of apoptosis beginning on or before E9 (Stevens, 1967; McCoshen \& McCallion, 1975; Nocka et al., 1990; Heaney et al., 2008). In these Kit and Kitlg heterozygous mutants, the wild-type allele is sufficient to rescue PGC viability at E13.5 and fertility in adult males. Loss of only membrane-bound KITLG in the Kitlgsld deletion leads to a mild phenotype characterized by partial PGC deficiency because of a proliferation defect (Fig. 1) (Flanagan et al., 1991; Tajima et al., 1991). At later stages, this mutation adversely affects PGC differentiation resulting in sterility. In KitlgSl17H mutants, the membrane-bound form is not functional due to absence of its cytoplasmic tail (Brannan et al., 1992). These mutants present a slight phenotype apparent after birth with anomalies in spermatogenesis, leading to sterility (Fig. 1). Surprisingly, KitlgSld and KitlgSl17H mutants have normal apoptosis when mice lacking KIT or KITLG have a high apoptotic rate, suggesting that soluble KITLG alone is sufficient to re-establishing normal apoptosis (Flanagan et al., 1991; Brannan et al., 1992). Nonetheless, neither KitlgSld nor Kitlgsl17H mutants are fertile, suggesting that membrane-bound KITLG is necessary for complete PGC development (proliferation and differentiation). Thus, the KIT/KITLG pathway controls the migration, proliferation and survival of PGCs during embryogenesis, and the proliferation, differentiation and the radial development of germ cells after birth.

Although loss of KIT and KITLG have similar effects on PGC development, only KitlgSl, KitlgSll and KitlgSlgb heterozygotes have 2-fold increase in occurrence of TGCT-affected males (Fig. 1) (Stevens, 1967; Heaney et al., 2008), suggesting that KIT is haplosufficient to promote TGCT formation. Interestingly, Kitlgsld allele has no effect on TGCT susceptibility (Heaney et al., 2008), suggesting that soluble KITLG is sufficient to suppress TGCT formation. The presence of EC clusters and the frequency of testicular abnormalities in KitlgSl and KitW 
heterozygous males remain to be evaluated. However, given that EC clusters are probably the origin of TGCTs and that some clusters have been described in mice lacking the PI3K binding site on KIT (Kissel et al., 2000), we expect to find EC clusters at least in KitlgSl, KitlgSlJ and Kitlgslgb heterozygous males. Determining whether soluble KITLG in Kitlgsld mutants reduces the frequency of these clusters, or whether KitW mutants also carry EC clusters without transformation into tumors, could highlight the molecular pathway involved in transformation of benign EC masses into malignant tumors.

\subsection{Pten}

Pten encodes a phosphatase that antagonizes both PI3K/AKT and MAPK signaling cascades through its dual phosphatase activities (Myers et al., 1997). Thus, PTEN is a key element of the KIT/KITLG pathway. Interestingly, PTEN regulates its own expression by stabilizing its transcriptional activator TRP53 (Tang \& Eng, 2006).

In the testis, PTEN is expressed in PGCs, but not in Sertoli cells (Kimura et al., 2003). Loss of PTEN leads to embryonic death, and heterozygotes have a high tumor incidence (Di Cristofano et al., 1998). PGCs lacking PTEN have defects in mitotic arrest and slow pluripotency loss after E13.5 (Fig. 1), and form EC clusters (Kimura et al., 2003). A high apoptotic rate is observed in the testis after E13.5 but remains insufficient to counterbalance abnormal proliferation. All mutant males develop bilateral TGCTs (Kimura et al., 2003). Pten transcript levels are reduced at least 2-fold in E13.5 gonads in MOLF males compared with 129 males (R. Zhu et al., 2007), suggesting that Pten is one of the genes on chromosome 19 that contribute to the high TGCT frequency. Furthermore, Pten is the only genetic variant that increases TGCT susceptibility to $100 \%$ in a mixed genetic background (Kimura et al., 2003).

Adenosine triphosphate-binding domains on PTEN regulate its subcellular localization (Lobo et al., 2009). Defect in these domains results in a predominantly nuclear localization, a DNA repair defect, and an inappropriate regulation of G1/S progression associated with a reduced apoptotic rate (He et al., 2011). PTEN mislocalization also leads to a reduced nuclear TRP53 level and transcriptional activity (He et al., 2011). Thus, PTEN plays an important role in cell growth and tumorigenesis, by regulating apoptosis, pluripotency, chromosome stability, DNA repair and cell cycle arrest (Kimura et al., 2003; Shen et al., 2007; Saal et al., 2008; He et al., 2011). Whether PTEN localization affects TGCT susceptibility is an open question.

\section{$3.3 \operatorname{Trp53}$}

The Trp53 gene encodes a tumor suppressor expressed in both PGCs and pre-Sertoli cells during embryogenesis, down-regulated after the birth in spermatogonia, and re-expressed in primary spermatocytes at pachytene, suggesting a role for TRP53 in control of meiosis (Almon et al., 1993; Schwartz et al., 1993). TRP53 activity is under the control of the PI3K/AKT pathway and depends of TRP53 phosphorylation $(\mathrm{Xu}, 2003)$. TRP53 regulates expression of several genes encoding mitotic regulators (i.e. CDKN1a, cyclin G1), the tumor suppressor PTEN, the pluripotent factor NANOG, and several apoptotic regulators (i.e. BAX, NOXA, PUMA) (Lin et al., 2005; Michalak et al., 2005; Tang \& Eng, 2006). TRP53 also activates PUMA, which controls activity of BCL2 components and induces a mitochondria- 
dependent apoptosis (Chipuk et al., 2004; D. Liu et al., 2010). Thus, TRP53 controls many key cellular pathways including apoptosis, pluripotency, G1/S cell cycle arrest, and meiosis.

DNA damage leads to deficiency of both germ and Sertoli cells after $\gamma$-irradiation of fetal testis due to apoptosis and a proliferation defect (Lambrot et al., 2007). PGC deficiency is associated with increased TRP53 activity and induction of BAX, PUMA and CDKN1a expression (Lambrot et al., 2007). In mice, loss of TRP53 phosphorylation leads to constitutive activation of TRP53 and in turn too embryonic lethality (D. Liu et al., 2010). In contrast, Trp53 \% mice have normal development but a significantly reduced lifespan due to high predisposition for spontaneous tumors, especially lymphomas (Donehower et al., 1992; Jacks et al., 1994). Disruption of the Trp53 gene in a pure 129 background increases TGCT incidence to 35-50\% (Fig. 1) (Rotter et al., 1993; Donehower et al., 1995). Homozygotes have a giant-cell degenerative syndrome characterized by abnormal primary spermatocytes that arrest meiosis at pachytene, and form clusters leading to germ cell deficiency but remain fertile (Rotter et al., 1993). Heterozygotes are fertile with a 2-fold increase of TGCT frequency in the 129 strain (Rotter et al., 1993; Donehower et al., 1995). In a 50/50 mixed background of C57BL/ 6 and 129, the TGCT incidence is reduced to $20 \%$ (Jacks et al., 1994). On these backgrounds, heterozygotes exhibit apparently normal testicular morphology (Rotter et al., 1993; Jacks et al., 1994; Muller et al., 2000). Thus, the combination of the Trp53 defect and the 129 genetic background results in a synergistic increase of giant-cell syndrome and TGCT penetrance.

\subsection{Dmrt1}

Dmrt1 encodes a male-specific transcriptional factor (Raymond et al., 1999). In the testis, DMRT1 is strongly expressed in pre-Sertoli cells and then in both Sertoli and undifferentiated germ cells from P1 onward (Raymond et al., 1999). DMRT1 disappears in germ cells that enter meiosis, suggesting that DMRT1 regulates initiation of either meiosis, mitotic arrest, or both, in a stage-dependent manner (Raymond et al., 2000; Fahrioglu et al., 2007). During embryogenesis, DMRT1 controls transformation of PGCs into gonocytes by regulating expression of pluripotent factors such as SOX2 and NANOG, and their entrance into a quiescent state by controlling some cell cycle inhibitors such as CDKN2d (Krentz et al., 2009; Murphy et al., 2010). After birth, the DMRT1 control of cell cycle kinases allows mitotic reactivation of male gonocytes. DMRT1 also plays a role in radial migration (Fahrioglu et al., 2007). Finally, DMRT1 acts as a transcriptional gatekeeper that controls the switch from mitosis to meiosis in the undifferentiated spermatogonia (Matson et al., 2010).

Interestingly, DMRT1 also has an indirect control of critical developmental steps by regulating expression of the retinaldehyde dehydrogenases ALDH1A1 and ADH4 (Matson et al., 2010). These enzymes are expressed in Sertoli cells and convert vitamin A-derived retinal into retinoic acid. Retinoic acid regulates cell proliferation, migration and differentiation (Bowles et al., 2006; Koubova et al., 2006). Catabolism of retinoic acid is facilitated by cytochrome P450 enzymes such as CYP26B1, which is highly expressed until E13.5 by mitochondria in Sertoli cells ( $\mathrm{Li}$ et al., 2009). Moreover, retinoic acid signaling is under the control of NANOS2, which is an RNA binding protein located in P-bodies, and is essential for male PGC development (Tsuda et al., 2003; A. Suzuki \& Saga, 2008). PGCs lacking CYP26B1 enter meiosis at E13.5 and have a high apoptotic rate (MacLean et al., 
2007). Similarly, NANOS2 loss affects gonocytes that re-enter in the proliferative phase at E15, immediately initiate meiosis, and finally are completely depleted at E18.5 (Tsuda et al., 2003; A. Suzuki \& Saga, 2008). DMRT1 loss in the 129 strain increases 10-fold the numbers of PGCs that escape mitotic arrest at E16.5 and return into pluripotent state to form EC clusters but without re-entry into meiosis as observed in Nanos 2 \% and Cyp26b1 \% mutants (Raymond et al., 2000; Krentz et al., 2009). Thus, NANOS2, CYP26B1 and consequently retinoic acid are required in PGCs for quiescence, meiosis and survival, whereas DMRT1 is only required for quiescence and differentiation despite its role on retinoic acid pathway. Furthermore, Dmrt1 / - males are sterile and 90\% of those develop TGCTs (Fig. 1) (Krentz et al., 2009). Interestingly, heterozygotes are fertile and the incidence of TGCTs is similar to that in 129 wild-type mice, suggesting that DMRT1 is haplo-insufficient for TGCTs.

\section{$3.5 A^{y}$ and Eif2s2}

The Agouti-yellow $(A y)$, which is a $\sim 170 \mathrm{~kb}$ deletion on chromosome 2 in mice includes the entire coding region of both Eif2s2 and Raly genes as well as a part of the Agouti gene (Michaud et al., 1994). Eif2s2 gene encodes the beta subunit of translation initiation factor eIF2 (Sarre, 1989). Raly encodes an RNA-binding protein that acts in pre-mRNA processing. Agouti encodes a signaling protein involved in the pigment synthesis in melanocytes (Michaud et al., 1994). Interestingly, the Ay deletion places the coding region of Agouti under the control of the Raly promoter, resulting in ectopic expression of Agouti (Duhl et al., 1994). As a result, Agouti is expressed in both PGCs and Sertoli cells, while RALY and eIF2s2 are lost in embryonic testes of Ay mice (Heaney et al., 2009). Homozygosity for $A y$ results in a pre-implantation lethality, whereas heterozygous $A y$ mice develop obesity, diabetes, yellow coat color traits, and have an increase of the propensity to develop a variety of spontaneous tumors (Duhl et al., 1994). Surprisingly, the $A y$ allele is the only genetic modifier known to suppress TGCT susceptibility in 129 mice and this phenotype results from loss of Eif2s2 (Lam et al., 2004; Heaney et al., 2009). Indeed, loss of one Eif2s2 allele decreases at least 2fold (less for $A y$ allele) the high TGCT susceptibility observed in the 129-M19/M19 males (Fig. 1) (Lam et al., 2004; Heaney et al., 2009). This protective effect is due to a rescue of the G1/S mitotic arrest from E16.5 onward, but without effect on apoptosis, suggesting that Eif2s2 deficiency affects only the mitotic activity but not the survival of PGCs (Heaney et al., 2009). In addition, spermatogenesis is normal in the mutant adult testis although the weight of testes is significantly reduced compared with their control 129-M19/M19 males, suggesting that reduced Eif2s2 impedes but does not repress adult germ cell maturation (Heaney et al., 2009).

By using genetic targeting in mice, several genes have been identified that play a crucial role in PGC development and transformation into TGCTs. These genes act in distinct pathways and understanding their interrelation is a challenge for future research.

\section{From mouse models to humans: Molecular basis of TGCT development}

In this section, we compare results for genetic studies of TGCT susceptibility in humans and in mice (Table 1), with an emphasis on gene functions and protein pathways that control development of the PGC stem cell lineage and that modulate susceptibility to TGCTs. 


\subsection{The KIT/KITLG pathway}

The KIT/KITLG pathway controls migration, proliferation, survival and differentiation of PGCs during embryogenesis and spermatogenesis. Although both Kit and Kitlg mutations affect development of several stem cell lineages including PGCs, only specific mutations in the Kitlg gene affect TGCT risk in mice (Heaney et al., 2008). In humans, four different GWAS identified allelic variations at the KITLG locus in individuals with TGCTs (Rapley et al., 2009; Turnbull et al., 2010; Kanetsky et al., 2009, 2011). Somatic mutations of KIT are also reported in men with TGCTs (Looijenga et al., 2003). In addition, deregulated expression of KITLG and KIT was found in TGCT biopsies (Murty et al., 1992). Thus, the KIT/KITLG pathway appears to be crucial for TGCT development both in humans and mice.

Similar evidence supports the hypothesis that the PI3K/AKT and MAPK signaling cascades modulate PGC transformation into TGCTs in humans and in mice:

- $\quad$ The SPROUTY 4 (SPRY4) gene encodes an inhibitor of MAPK signaling by inhibiting RAS activation (Leeksma et al., 2002). SPRY4 is associated with TGCT susceptibility in humans (Rapley et al., 2009; Turnbull et al., 2010; Kanetsky et al., 2009, 2011).

- TRP53 deficiency is a potent but unusual modifier of TGCT susceptibility in both humans and mice. Although common in many cancers in humans (K. Suzuki \& Matsubara, 2011), somatic TRP53 mutations are exceptionally rare in TGCTs in humans (Murty et al., 1994; Peng et al., 1995); somatic Trp53 mutations do not appear to have been surveyed in mice. By contrast, germline TRP53 mutations are the molecular basis for Li-Fraumeni syndrome, which increases susceptibility to various cancers including TGCTs (Malkin et al., 1990), and germline Trp53 mutations also increase susceptibility to many cancers including TGCTs in mice (Rotter et al., 1993; Donehower et al., 1995). Together these observations suggest that TRP53 mutations act in the soma, rather than in the germline, to promote transformation of PGCs.

Various elements of TRP53-mediated apoptosis have been implicated in TGCT development. Indeed, variation within the BAK1 gene is associated with TGCT cases in humans (Rapley et al., 2009; Turnbull et al., 2010). In addition, expression of Cox15, which encodes the mitochondrial cytochrome $\mathrm{C}$ oxidase assembly protein that is essential for the cell death program, is altered in testes of 129-M19 mice, which have a dramatically elevated TGCT risk (R. Zhu et al., 2007).

Interestingly, double homozygosity for the KITLG and DMRT1 risk haplotypes increases risk 14-fold in humans (Kanetsky et al., 2011), suggesting that these haplotypes affect TGCTs in a non-additive manner. These interactions could arise either through pathways downstream of KIT that regulate DMRT1 activity, or through membrane-bound KITLG activating an intrinsic pathway in Sertoli cells that modulate the DMRT1 or the retinoic acid pathways. Pre-Sertoli cells are depleted in KitlgSl mutants (Tajima et al., 1991) and their development is altered in Dmrt1 - - mice (Raymond et al., 2000; Krentz et al., 2009), suggesting that DMRT1 and KITLG are essential to Sertoli cell development and that preSertoli cells might be involved in tumorigenesis, reinforcing the hypothesis of functional relations between KIT/KITLG and DMRT1. Finally, it is possible that at least one element of the KIT/KITLG pathway is a target gene of the transcriptional regulator DMRT1. 


\begin{tabular}{|c|c|c|c|c|c|c|}
\hline \multicolumn{2}{|c|}{$\begin{array}{l}\text { Chromosome } \\
\text { \# OTL }\end{array}$} & \multicolumn{2}{|c|}{ Location } & Gene & \multicolumn{2}{|l|}{ Reference } \\
\hline 2 & D2S171 & $2 \mathrm{p} 23$ & $12 \mathrm{~A} 1$ & DNMT3A? & Crockford et al., 2006 & \\
\hline 3 & $\begin{array}{l}\text { D3S1607- } \\
\text { D3S1282 }\end{array}$ & $3 q 26$ & $3 \mathrm{~F} 2$ & TERC & Crockford et al., 2006 & \\
\hline \multirow[t]{2}{*}{4} & rs4699052 & $4 \mathrm{q} 24$ & $3 G 3$ & CENP-E? & Rapley et al., 2009 & \\
\hline & $\begin{array}{l}\text { Somatic } \\
\text { mutations }\end{array}$ & $4 q 12$ & $5 \mathrm{C} 3$ & KIT & Looijenga et al., 2003 & \\
\hline 5 & rs4624820 & $5 q 31$ & $18 \mathrm{~B} 3$ & SPRY4 & $\begin{array}{l}\text { Rapley et al., } 2009 \\
\text { Kanetsky et al., 2009, } 2011 \\
\text { Turnbull et al., 2010 }\end{array}$ & \\
\hline & & $5 q 31$ & 18B2 & DND1 & & $\begin{array}{l}\text { Noguchi \& Noguchi, } 1985 \\
\text { Youngren et al., } 2005\end{array}$ \\
\hline & & $5 q 31$ & 18B2 & PAIP2? & & Asada et al., 1994 \\
\hline & $\begin{array}{l}\text { rs } 2736100 \\
\text { rs4635969 }\end{array}$ & $5 p 15$ & $13 \mathrm{C} 1$ & TERT & Turnbull et al., 2010 & \\
\hline 6 & rs 210138 & $6 \mathrm{p} 21$ & $17 \mathrm{~A} 3$ & BAK1 & $\begin{array}{l}\text { Rapley et al., } 2009 \\
\text { Turnbull et al., } 2010\end{array}$ & \\
\hline \multirow[t]{2}{*}{9} & $\begin{array}{l}\text { rs755383 } \\
\text { rs7040024 }\end{array}$ & 9p24 & $19 B$ & DMRT1 & $\begin{array}{l}\text { Turnbull et al., } 2010 \\
\text { Kanetsky et al., } 2011\end{array}$ & $\begin{array}{l}\text { Youngren et al., } 2003 \\
\text { Krentz et al., 2009 }\end{array}$ \\
\hline & & $9 q 24$ & $19 \mathrm{C} 1$ & SMARCA2? & & Youngren et al., 2003 \\
\hline \multirow[t]{5}{*}{10} & & $10 \mathrm{p} 11$ & $18 \mathrm{~A} 1$ & MAP3K8? & & Anderson et al., 2009a \\
\hline & & $10 \mathrm{q} 23$ & $19 \mathrm{C} 1$ & PTEN & & Kimura et al., 2003 \\
\hline & & $10 \mathrm{q} 24$ & $19 \mathrm{C} 3$ & COX15? & & R. Zhu et al., 2007 \\
\hline & & $10 \mathrm{q} 25$ & 19D2 & GFRA1? & & $\begin{array}{l}\text { Matin et al., } 2000 \\
\text { Youngren et al., } 2003\end{array}$ \\
\hline & & $10 \mathrm{q} 26$ & 19D3 & $\begin{array}{l}\text { NANOS1? } \\
\text { EIF3a? }\end{array}$ & & $\begin{array}{l}\text { Matin et al., } 2000 \\
\text { Youngren et al., } 2003\end{array}$ \\
\hline \multirow[t]{3}{*}{12} & $\begin{array}{l}\text { rs } 995030 \\
\text { rs4474514 } \\
\text { rs1508595 }\end{array}$ & $12 \mathrm{q} 21$ & 10D1 & KITLG & $\begin{array}{l}\text { Rapley et al., } 2009 \\
\text { Kanetsky et al., 2009, } 2011 \\
\text { Turnbull et al., 2010 }\end{array}$ & $\begin{array}{l}\text { McCoshen \& McCallion, } 1975 \\
\text { Copeland et al., } 1990 \\
\text { Heaney et al., 2008 }\end{array}$ \\
\hline & $\begin{array}{l}\text { D12S85- } \\
\text { D12S368 }\end{array}$ & $12 \mathrm{q} 13$ & (15F1?) & $\begin{array}{l}\text { HDAC7? } \\
\text { DDX23? }\end{array}$ & Crockford et al., 2006 & \\
\hline & rs2900333 & $12 \mathrm{p} 13$ & 6G1 & ATF7IP & Turnbull et al., 2010 & \\
\hline 17 & & $17 \mathrm{p} 13$ & 11B13 & TRP53 & & $\begin{array}{l}\text { Donehower et al., } 1995 \\
\text { Rotter et al., } 1993\end{array}$ \\
\hline \multirow[t]{2}{*}{18} & D18S5 & $18 \mathrm{q} 22$ & $18 \mathrm{E} 4$ & DOK6? & $\begin{array}{l}\text { Murty et al., } 1994 \\
\text { Crockford et al., } 2006\end{array}$ & \\
\hline & & $18 \mathrm{q} 21$ & $18 \mathrm{E} 2$ & $\begin{array}{l}\text { MBD1/MBD2, } \\
\text { MAPK4 ? }\end{array}$ & & Anderson et al., 2009a \\
\hline 20 & & $20 \mathrm{q} 11$ & $2 \mathrm{H} 1$ & EIF2s2 & & Heaney et al., 2009 \\
\hline 21 & & $21 \mathrm{q} 22$ & $10 \mathrm{C} 1$ & DNMT3L & Minami et al., 2010 & \\
\hline \multirow[t]{3}{*}{$\mathrm{X}$} & Tgct1 locus & $\mathrm{Xq} 27$ & (12C1?) & SPANX? & $\begin{array}{l}\text { Rapley et al., } 2000 \\
\text { Crockford et al., } 2006\end{array}$ & Hammond et al., 2007 \\
\hline & $\begin{array}{l}\text { DXS548 - } \\
\text { DXS8091 }\end{array}$ & $\mathrm{Xq} 27$ & XA7 & FMR1? & Crockford et al., 2006 & \\
\hline & & $\mathrm{Xq} 28$ & XA7 & $\mathrm{DKCl} ?$ & Skotheim et al., 2001 & \\
\hline \multirow[t]{2}{*}{ Y } & gr/gr deletion & Yq11 & $?$ & $\begin{array}{l}\text { DAZ, BPY2, } \\
\text { CDY1 }\end{array}$ & Nathanson et al., 2005 & Anderson et al., 2009b \\
\hline & & Yp11 & YA1 & TSPY & $\begin{array}{l}\text { Y.F. Lau, } 1999 \\
\text { Akimoto et al., } 2010\end{array}$ & \\
\hline
\end{tabular}

Table 1. Candidate modifiers of TGCTs in humans and their orthologues in mice. 
Other tyrosine kinase receptors that are expressed in PGCs may also contribute to TGCT development. A strong candidate is RET, which is activated by the growth factor GDNF receptor GFRA1. Gfra1 gene is located at 19D3 in mice, within a locus that was proposed as candidate TGCT modifier (Matin et al., 1999; Youngren et al., 2003). Furthermore, Ret is a known proto-oncogene (Grieco et al., 1990) and its expression is indirectly under the control of the TGCT modifier DMRT1 (Krentz et al., 2009). Allelic variations were identified at 18q21 in TGCTs in humans (Murty et al., 1994; Crockford et al., 2006). This locus contains the Docking protein 6 (DOK6) gene that plays a role in RET signaling cascade (Crowder et al., 2004). Interestingly, Dok6 gene is located on chromosome 18 in mice, reinforcing the hypothesis of the role of other tyrosine kinase receptors such as GDNF receptors on TGCT development (Anderson et al., 2009a).

\subsection{Telomerase and TGCTs}

By extending the TTAGGG telomeric nucleotide repeats, telomerase counterbalances loss of telomere length that usually occurs during cell division, and thus preserves chromosomal integrity (Venteicher et al., 2009). The active telomerase complex involves TERT (telomerase inverse transcriptase), the RNA component TERC, the ribonucleoprotein dyskerin (encoded by the X-linked DCK1 gene) and several other cofactors (Venteicher et al., 2009). Telomerase is activated by the telomerase Cajal body protein-1 (TCAB1) which is encoded by the WRAP53 gene (Jady et al., 2004).

Mutations in TERT (Marrone et al., 2007), TERC (Vulliamy et al., 2001), DKC1 (Heiss et al., 1998) and more recently WRAP53 (Zhong et al., 2011), which all lead to absence or dysfunction of telomerase, are found in congenital dyskeratosis, a human genetic deficiency characterized by abnormal skin pigmentation, bone marrow failure, and an elevated tumor frequency. Telomere defects are also associated with segmental progeria syndrome, which is characterized by accelerated ageing and is associated with a severe deficiency of adult stem cells in brain, bone marrow and testis (Burtner \& Kennedy, 2010). Furthermore, telomerase dysfunction enhances tumor incidence in mice (Blasco et al., 1997). Thus, telomerase seems to play an essential role in stem cell development and cancer formation.

Specific markers of TGCT susceptibility have been recently identified in humans at 12p13, which contains the gene encoding ATF7IP, an enhancer of TERT and TERC transcription, and at 5p15 within TERT (Turnbull et al., 2010). Furthermore, a marker of familial TGCT risk was located $50 \mathrm{~kb}$ downstream of TERC (Crockford et al., 2006), and amplification of human Xq28 containing DCK1 was found in TGCTs (Skotheim et al., 2001). In mice, the primordial germ cell tumor 1 locus (pgct1), that contains Tert on chromosome 13, has been identified as an enhancer of TGCT susceptibility (Muller et al., 2000). Furthermore, loss of Tert in mice leads to PGC deficiency which increases accross generations, due to both reduced proliferation and increased apoptosis (Lee et al., 1998). This phenotype is more severe in males where PGC deficiency is complete at the sixth generation (Lee et al., 1998). Taking together, these observations highlight the involvement of telomerase and telomere biology in TGCT development.

Interestingly, pgct1 locus interacts with TRP53 to modulate TGCT susceptibility in mice (Muller et al., 2000), and Wrap53 is a natural antisense transcript of Trp53 and regulates the levels of TRP53 in response to DNA damage (Mahmoudi et al., 2009). Furthermore, 
telomerase dysfunction activates TRP53-dependent apoptosis (Chin et al., 1999). By contrast, progeria-like syndromes have been associated with alterations in TRP53-dependent apoptosis (D. Liu et al., 2010). Given these results and that both congenital dyskeratosis and segmental progeria affect similar stem cell lineages as KIT/KITLG defect (melanogenesis, gametogenesis and hematopoiesis), we propose an interrelation between KIT/KITLG pathway, via TRP53, and telomerase, via TERT and WRAP53, during embryogenesis that contributes to tumorigenesis.

\subsection{Sex chromosomes and TGCTs}

Males with Klinefelter's syndrome (also known as XXY syndrome) have 50-fold greater TGCT risk (Gustavson et al., 1975). Secondly, gain of X chromosomes has been described in TGCTs in humans (Peltomaki et al., 1990; Skotheim et al., 2001). Third, chromosome $X$ from the C57BL/6 strain reduces tumor incidence in 129-Ter/Ter mice (Hammond et al., 2007), suggesting that genes linked to chromosome $\mathrm{X}$ both in mice and humans modulate TGCT incidence. In addition to DCK1 at Xq28 in humans, other interesting genes are Sperm protein associated with the nucleus mapped to the X chromosome (SpanX) clusters at Xq27, a locus named Tgct1, which has been linked with bilateral TGCTs and undescended testicular syndrome in humans (Rapley et al., 2000; Kouprina et al., 2004; Crockford et al., 2006). Although the function of SPANX proteins is unknown, evidence is accumulating that suggests their involvement in tumorigenesis. For example, SPANX genes are deregulated in Down's syndrome subjects who have undescended testis and an increased risk of TGCTs (Satge et al., 1997), further suggesting interaction of genes located on chromosome $X$ and chromosome 21 for TGCT susceptibility. SPANX genes have a testis-specific expression that is conserved in rodents and humans, and was also detected in EC clusters and TGCTs (Westbrook et al., 2004; Salemi et al., 2006).

Similarly, a complete loss of chromosome $\mathrm{Y}$ in humans (45 XO karyotype) reduces TGCT susceptibility (Soh et al., 1992). Furthermore, the rare $g r / g r$ deletion of the Y chromosome that removes part of the AZFc region (Yq11) is found in men with infertility and lowpenetrance for TGCT susceptibility (Nathanson et al., 2005). This deletion affects DAZ (deleted in azoospermia), BPY2 (Basic protein, Y-linked) and CDY1 (chromodomain protein, Y-linked 1). DAZ encodes an RNA-binding protein that interacts with the P-body component PUM2 in PGCs (Moore et al., 2003). The functions of CDY1 and BPY2 remain unknown. Moreover, aberrant expression of testis-specific protein on $Y$ (TSPY) at Yp11 in humans may contribute to predisposition for TGCTs (Y.F. Lau, 1999), revealing a differential effect of the $\mathrm{Y}$ chromosome on TGCT risk. In mice, neither the MOLF-derived nor the C57BL/6-derived chromosome $Y$ significantly affects susceptibility in 129 mice (Hammond et al., 2007). However, by using a sex-reversed mouse model, TGCTs were not found in the absence of the $\mathrm{Y}$ chromosome (Anderson et al., 2009b). Furthermore, a possible interaction, which suppress TGCT susceptibility in mice, was described between the Y-linked genes, which have a low-penetrance for TGCTs, and either the Dnd1 gene (chromosome 18) or the genes located on chromosome 19 (perhaps Dmrt1 given its role in sex differentiation and in TGCT susceptibility) (Anderson et al., 2009b). This hypothesis is supported by the fact that Dnd1 has sex-dependent effects on PGC survival and tumor susceptibility. Indeed, Dnd1 is differentially expressed in XX (down-regulation) and XY (up-regulation) gonads (Youngren et al., 2005). Loss of Dnd1 leads to PGC deficiency that increases with age in males, but not 
in females (T. Noguchi \& M. Noguchi, 1985). Furthermore, the few mutant germ cells that successfully migrate to the gonad give rise to mature oocytes in females, while in testes, they give rise to TGCTs in 95\% of cases (Cook et al., 2009).

Thus, sex chromosomes seem to play a crucial role in TGCT susceptibility. Identification of the candidate genes and of their interrelation remains to be elucidated.

\subsection{RNA biology, epigenetic regulation and TGCTs}

The translational complex eIF2 is composed of the alpha (eIF2s1), beta (eIF2s2) and gamma (eIF2s3) subunits (Sarre, 1989). Eif2s2 is a TGCT modifier in mice (Heaney et al., 2009), but remains to be confirmed in humans. Eif2s3 is located on both Y (Eif2s3y) and X (Eif2s3x) chromosomes in mice (in humans, no $\mathrm{Y}$ homologues have been found) (Ehrmann et al., 1998). Given the role of sex chromosomes discussed above, Eif2s3 should be considered as a candidate for TGCT susceptibility. EIF4E is another translational factor which acts downstream of PI3K/AKT pathway. Interestingly, eIF4E is a potent oncogene (Wendel et al., 2004), regulated by the poly(A)-binding protein and its cofactor PAIP2 (Yanagiya et al., 2010). Paip2 is located on mouse chromosome 18 near the Ter locus (Asada et al., 1994). Finally, Eif3a encodes another translational factor located on chromosome 19 in mice within a region involved in TGCT susceptibility (Matin et al., 1999; Youngren et al., 2003), but its direct role in TGCTs remains to be tested in mice and humans.

Translation is under the control of P-bodies, which regulate many mRNA processes (i.e. post-transcriptional regulation, degradation, storage, transport, and stabilization) in cells under normal physiological conditions or in response to stress (Seydoux \& Braun, 2006; Parker \& Sheth, 2007). P-bodies are essential for male PGC development and probably also for tumorigenesis given the involvement of its major components (Hayashi et al., 2008; K.M. Nelson \& Weiss, 2008). DDX3, which encodes a helicase of P-body, is located on both Y $(D D X 3 y)$ and $X(D D X 3 x)$ chromosomes in mice and humans, and has been identified as a tumor suppressor (Chao et al., 2006). Given the role of sex chromosomes and the close location of $D d x 3 y$ and Eif2s3y in mice, DDX3 should also be considered as a candidate for TGCT susceptibility. Interestingly, another DDX gene (DDX23) is located at $12 \mathrm{q} 13$ in humans, a locus which has been associated with TGCTs (Crockford et al., 2006). In addition, PGCs lacking DICER1, another helicase, are depleted around E13.5 in mice (Hayashi et al., 2008), suggesting an essential role of Dicer1 in PGC development. Dicer1 has been also identified as a potential tumor suppressor in mice and probably also in humans (Su et al., 2010). Nanos1, which encodes an RNA binding protein, is located on chromosome 19 in mice, within a region involved in TGCT susceptibility (Matin et al., 1999; Youngren et al., 2003). Finally, allelic variations within the X-fragile mental retardation (FMR) genes (FMR1, FMR1nb and FMR2) at Xq27 in humans have been identified in TGCTs (Crockford et al., 2006). These genes encode RNA binding proteins that are involved in translation regulation through an interaction with the DICER and Argonaute proteins (Jin et al., 2004). The number of CGG trinucleotide repeats in the 5'-untranslated region of FMR1 and their DNA methylation pattern determine the severity of FMR-related pathogenicity (Fu et al., 1991; McConkie-Rosell et al., 1993). Furthermore, loss of Fmr1 alters both proliferation and differentiation of several stem cell lineages including PGCs (Castren et al., 2005), suggesting a role of FMR1 in TGCT susceptibility. 
Additional evidence shows an association between DNA methylation and TGCT susceptibility. First, DNA methylation in male PGCs is largely erased at E10.5-E11.5 and partially reestablished at E13-E14 (Sasaki \& Matsui, 2008). This epigenetic reprogramming completely overlaps the critical period for TGCT formation (E11.5-E13.5) (Stevens \& Little, 1954; Stevens, 1967). Secondly, the DNA methyltransferase DNMT3L has been recently identified as a novel marker of TGCTs in humans (Minami et al., 2010), in accordance with the fact that TGCTs have a distinct epigenetic profile from other cancers (Ushida et al., 2011). Third, other genetic markers for TGCTs have been identified: (1) in humans, at 2p23 which contains DNMT3A, and at 12q13 which contains gene encoding the histone deacetylase HDAC7 (Crockford et al., 2006); (2) in mice, on a region of chromosome 18 that contains genes encoding two methyl-binding proteins MBD1 and MBD2 (Anderson et al., 2009a), and on chromosome 19 at a region that contains the remodeling chromatin factor Smarca2 (Matin et al., 1999; Youngren et al., 2003). Other studies correlate up-regulation of DNMT3A with demethylation of specific loci in TGCTs in humans (Ishii et al., 2007), and inhibition of both DNMTs and HDACs with prevention of cancer formation (W.G. Zhu \& Otterson, 2003). Another TGCT marker has been identified at 4q24 in humans near the CENP-E gene that encodes a centromeric-associated protein required for establishing and maintaining of the mitotic checkpoint (Abrieu et al., 2000; Rapley et al., 2009). CENP-E is described in mice as tumor-suppressing or -promoting factor depending on the context (Weaver et al., 2007). Interestingly, TRP53 has been associated with DNA demethylation (Ashur-Fabian et al., 2010) and several TRP53-target genes show aberrant methylation pattern in TGCTs in humans (Christoph et al., 2007).

\section{Transgenerational genetic effects on TGCT susceptibility}

Growing evidence suggests an alternative molecular basis of inheritance that complements conventional Mendelian inheritance with a similar strength, frequency and persistence across multiple generations (V.R. Nelson \& Nadeau, 2010). These alternatives could involve four different forms: (1) environmental factors that create an epigenetic state that persists across generations (transgenerational environmental effects); (2) ancestral genetic factors that are sufficient to initiate epigenetic inheritance (transgenerational genetic effects); (3) environmental factors that have an epigenetic effect only in genetically predisposed individuals (transgenerational gene-environmental interactions); and (4) genetic variants in parents and others in offspring that interact to create an epigenetic state in offspring (transgenerational gene-gene interactions) (V.R. Nelson \& Nadeau, 2010). The evidence for transgenerational genetic effects, as well as the implication inheritance of TGCT susceptibility will be discussed in this section.

\subsection{Environmental effects}

Pesticides and insecticides were intensively used in agricultural industries during previous decades. These chemicals, which are now found in foods and water, contain endocrine disruptors that act primarily through nuclear hormone receptors such as estrogen and androgen receptors (Danchin et al., 2011). In utero, perinatal or neonatal exposures affect male reproduction leading to infertility with an increase of testicular abnormalities and germ cell cancers in humans (A. Giwercman \& Y.L. Giwercman, 2011). These effects can be 
reversible, permanent or even transgenerational, and involve alterations of DNA methylation (Anway et al., 2005; Danchin et al., 2011; Kalfa et al., 2011).

Other natural nutrients could also modulate predisposition to disease such as TGCTs. As discussed above, vitamin A plays an essential role in PGC development and might also influence TGCT susceptibility. Similarly, folate which is a methyl-donor nutrient affects DNA methylation and is essential for PGC development (Danchin et al., 2011). Determining the effects of folate and vitamins on TGCT susceptibility, and whether supply of these nutrients can reverse TGCT development is a challenge for future research both in rodents and humans. A related challenge is understanding relation between genetic modifiers and environmental factors on TGCT susceptibility.

\subsection{Parent-of-origin effects}

While environmental factors could affect reproductive health across generations in a parentof-origin manner (Anway et al., 2005; Kalfa et al., 2011), two examples reveal similar parental-dependent transgenerational effect of TGCT modifier genes in mice.

Loss of KITLG (KitlgSl, KitlgSll and KitlgSlgb) in mice causes 2-fold increase of TGCT susceptibility in the 129 strain (Stevens, 1967; Heaney et al., 2008). Surprisingly, among the progeny of the KitlgSlgb/+ males, wild-type sons never develop TGCTs (5\% expected), whereas wild-type sons of the reciprocal crosses (maternal Kitlgslgb allele) are affected at the expected rate (Fig. 2) (Heaney et al., 2008). Thus, absence of one Kitlg allele in the male germline leads to an epigenetic change that affects TGCT susceptibility in the predisposed 129 strain. Whether this protective effect persists across generations is currently being tested (E. Leung \& J.H. Nadeau). Determining the molecular basis of this epigenetic modification, and whether other Kitlg mutant males (i.e. KitlgSl and KitlgSl) have similar effects remain to be determined.
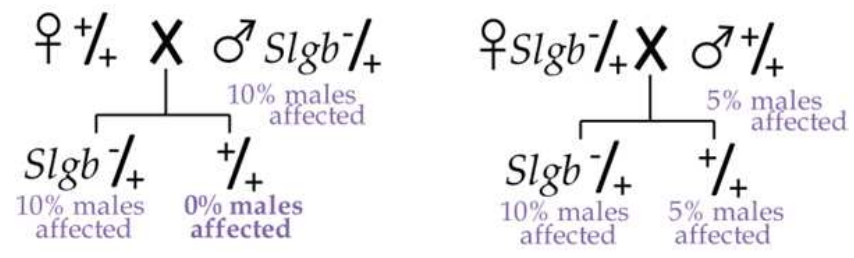

Fig. 2. Example of parental transgenerational effects in a mouse model for TGCTs.

Similarly, wild-type sons of females with the $A y$ allele, which acts as a TGCT suppressor due to the deletion of Eif2s2, have a $65 \%$ of risk being affected (80\% expected) (Heaney et al., 2009; J.D. Heaney \& J.H. Nadeau, unpublished), revealing another example of a transgenerational effect on TGCTs transmitted in this case through the maternal germ-lineage.

\subsection{Gene-gene interactions}

The intercross of Trp53 -/+ and KitWv -/+ mice yields $\left\{K_{i} W_{v}-\%_{+} ; \operatorname{Trp} 53-/+\right\}$ double heterozygotes which are intercrossed to generate double homozygotes (Jordan et al., 1999). Surprisingly, $\left\{\mathrm{Kit}_{\mathrm{Wv}}\right.$-/.; Trp53 - / \} males are fertile due to a rescue of PGCs at E13.5 (Jordan et al., 1999), confirming that the high rate of apoptosis observed in Kit Wo -/- embryonic gonads 
depends on KIT/KITLG-TRP53 interactions. Loss of both TRP53 alleles is necessary to rescue fertility because both $\left\{\mathrm{KitWv}_{-} /-; \operatorname{Trp} 53+/+\right\}$ and $\left\{\mathrm{KitWv}_{-} /-; \operatorname{Trp} 53-/+\right\}$ males are sterile (Jordan et al., 1999). Interestingly, only $10 \%$ of normal $\{$ KitWo $-/ . ;$ Trp53 $-/\}$ germ cells are present in the adult testes, compared to $34 \%$ after birth. This deficiency in the adult testes correlates with presence of testicular abnormalities (germ cell radial migratory defect, meiotic failure and apoptosis). As discussed above, these testicular abnormalities could be the origin of TGCTs. Unfortunately, this study was conducted on a mixed background and the TGCT susceptibility of these offspring remains to be investigated in the 129 strain. However, intercrosses of Trp53 / + and KitlgSl - / mice give the double heterozygous $\{\mathrm{KitlgSl}$ $\left.-t_{+} ; \operatorname{Trp} 53-/+\right\}$ males that have a surprising 4 -fold reduced TGCT frequency $(7 \% ; 26 \%$ expected) (Lam et al., 2004), suggesting that Kitlg and Trp53 genes can interact to counterbalance their effects on TGCT susceptibility. The effect of this gene interaction on PGC development remains to be investigated.

KitlgSlJ allele interacts also with the MOLF-derived chromosome 19. Indeed, the double heterozygotes $\{$ KitlgSlI $-/+; \mathrm{M} 19 /+\}$ have a significantly increased TGCT susceptibility $(57 \%$; $45 \%$ expected) due to an increase in the number of bilateral cases (Lam et al., 2004). These results suggest that KitlgSl hemizygosity potentiates the effect of M19 on TGCT susceptibility.

The intercross of C57BL/6-Bax - / and 129-Ter/Ter mice yields double homozygotes \{Ter/Ter; Bax $/$. $\}$ that show at least 50\% of PGCs rescued at E13.5 (Cook et al., 2009), demonstrating that the PGC deficiency in 129-Ter/Ter males is due to BAX-mediated apoptosis. However, rescued PGCs are completely lost in adult, suggesting that mechanisms affecting PGC development after E13 are BAX-independent in 129-Ter/Ter mice. This hypothesis is supported by the observation that loss of BAX does not affect the TGCT frequency, which remains elevated (91\%; $94 \%$ expected) (Cook et al., 2009). Surprisingly, the $\left\{\right.$ Ter $/$ Ter; Bax $\left.-\gamma_{+}\right\}$ males have a 2 -fold decrease of tumor risk and $\{$ Ter/Ter; Bax $+/+\}$ males do not develop TGCTs (Cook et al., 2009). This protective phenotype is interesting but we cannot determine whether it results from a genetic background effect (C57BL/6 vs 129) or from a genetic interaction (Bax vs Dnd1). Backcrosses of the double homozygotes $\{$ Ter/Ter; Bax $-/$ - $\}$ to pure C57BL/ 6 background mice suppress the TGCT susceptibility (Cook et al., 2011), favoring a background effect on TGCT susceptibility.

The double $\{$ Ter/Ter; Sf1 $/+\}$ mutants in the 129 strain have a 2-fold reduction in risk due to a reduced frequency of bilateral tumors (R. Zhu et al., 2010). Despite this protective effect on TGCT formation, all mutant males are sterile due to a complete germ cell deficiency (R. Zhu et al., 2010). This phenotype is similar as those observed in the $\{$ Ter $/$ Ter; Bax $-/+\}$ males suggesting a common pathway involving both SF1 and BAX on PGC deficiency in 129Ter/Ter mice.

The interaction of Ter allele with the four risk alleles KitlgSlJ, mutated Trp53, M19 and Ay in the respective double heterozygous males increased TGCT susceptibility at least 2-fold in the 129 strain by enhancing the frequency of bilateral tumors (Lam et al., 2007). Surprisingly, all $\left\{\mathrm{Ter} /+_{+}+/+\right\}$males of these four intercrosses also have a 2 -fold increase in TGCT frequency, suggesting transgenerational epistasis that acts only in the presence of the Ter allele in the offspring generation. The mechanism underlying interactions with the Ter allele remains elusive, although the new role of DND1 in the micro-RNA biology (Kedde et al., 2007) may be one ways by which this transgenerational effect acts. 


\section{Conclusions}

Mouse models of TGCTs have made major contributions to stem cell biology, developmental biology of the PGC lineage, and genetic and epigenetic studies of TGCT susceptibility.

The germ cell lineage, which has been termed the 'mother of all stem cells', carries DNA and other molecular features that together constitute our genetic and epigenetic heritage (Donovan, 1998). Controlling differentiation and proliferation of PGCs, which belong to the only lineage of cells that naturally show totipotency is therefore essential for maintaining their integrity. Many factors have been shown to affect molecular mechanisms regulating pluripotency versus differentiation, proliferation versus death, and migration versus stasis during normal PGC development (Pesce et al., 1993; Lin et al., 2005; Shen et al., 2007; Heaney et al., 2009; Murphy et al., 2010; Cook et al., 2011). In parallel, insights are beginning to emerge about the ways in which anomalies in these factors and processes lead to transformation (Rotter et al., 1993; Kimura et al., 2003; Youngren et al., 2005; Heaney et al., 2008; Krentz et al., 2009). Despite their fundamental relevance to understanding important aspects of human biology, these studies are obviously difficult to conduct in humans. Thus, studies of PGCs and their transformed derivatives in mice will likely remain relevant to our understanding of the genetics and developmental origins of TGCTs in humans.

Despite being a common cancer in young men (Buetow, 1995), with heritable TGCT risk among the highest of all cancers (Gilbert et al., 2011), the genetic control of inherited susceptibility has proven to be remarkably elusive. However, with the availability of complete panels of genetic markers, high-throughput assays, and increasingly rigorous analytical methods, both linkage analysis and GWAS have begun to yield results. The first breakthrough involved the gr/gr deletion on the X chromosome (Nathanson et al., 2005), followed more recently with GWAS evidence for KITLG, SPRY4, DMRT1, TERT, BAK1 and ATF7IP as strong candidate susceptibility genes (Rapley et al., 2009; Turnbull et al., 2010; Kanetsky et al., 2009, 2011). The recent evidence for involvement of KITLG in humans was anticipated by corresponding evidence in mice involving mutations in the Kitlg gene (Heaney et al., 2008). The fact that some but not all Kitlg mutants affect susceptibility implies that allele-specific tests and structure-function studies will both be important to understand the ways in which KITLG variants affect TGCT susceptibility in humans.

More recently, heritable epigenetic changes have been shown to strongly influence TGCT risk in mouse models. In particular, TGCT modifier genes in the parental generation were shown to interact with the Dnd1 modifier to increase both the number of affected males and the proportion of bilateral cases (Lam et al., 2007). Similar evidence for transgenerational genetic effects has also been reported for Kitlg mutants (Heaney et al., 2008). These and related discoveries suggest that heritable epigenetic changes might be as important as conventional genetic effects in controlling inherited TGCT risk, and might account for the substantial difference in risk between sons and brothers of cases (Hutter et al., 1967). Identifying the nature of these epigenetic factors, characterizing their molecular mechanisms, and testing their contribution to TGCT susceptibility in humans and in mice remain major challenges. 


\section{Acknowledgement}

Preparation of this review was supported with funds from NCI CA75056 and NIH Pioneer Award DP-12560002

\section{References}

Abrieu, A.; Kahana, J.A.; Wood, K.W. \& Cleveland, D.W. (2000). CENP-E as an essential component of the mitotic checkpoint in vitro. Cell, Vol.102, No.6, (September 2000), pp.817-826, ISSN 0092-8674

Albrecht, K.H. \& Eicher, E.M. (2001). Evidence that Sry is expressed in pre-Sertoli cells and Sertoli and granulosa cells have a common precursor. Dev Biol, Vol.240, No.1, (December 2001), pp.92-107, ISSN 0012-1606

Almon, E.; Goldfinger, N.; Kapon, A.; Schwartz, D.; Levine, A.J. \& Rotter, V. (1993). Testicular tissue-specific expression of the p53 suppressor gene. Dev Biol, Vol.156, No.1, (March 1993), pp.107-116, ISSN 0012-1606

Anderson, P.D.; Nelson, V.R.; Tesar, P.J. \& Nadeau, J.H. (2009a). Genetic factors on mouse chromosome 18 affecting susceptibility to testicular germ cell tumors and permissiveness to embryonic stem cell derivation. Cancer Res, Vol.69, No.23, (December 2009), pp.9112-9117, ISSN 1538-7445

Anderson, P.D.; Lam, M.Y.; Poirier, C.; Bishop, C.E. \& Nadeau, J.H. (2009b). The role of the mouse y chromosome on susceptibility to testicular germ cell tumors. Cancer Res, Vol.69, No.8, (April 2009), pp.3614-3618, ISSN 1538-7445

Anway, M.D.; Cupp, A.S.; Uzumcu, M. \& Skinner, M.K. (2005). Epigenetic transgenerational actions of endocrine disruptors and male fertility. Science, Vol.308, No.5727, (June 2005), pp.1466-1469, ISSN 1095-9203

Asada, Y.; Varnum, D.S.; Frankel, W.N. \& Nadeau, J.H. (1994). A mutation in the Ter gene causing increased susceptibility to testicular teratomas maps to mouse chromosome 18. Nat Genet, Vol.6, No.4, (April 1994), pp.363-368, ISSN 1061-4036

Ashur-Fabian, O.; Har-Zahav, A.; Shaish, A.; Wiener Amram, H.; Margalit, O.; Weizer-Stern, O.; Dominissini, D.; Harats, D.; Amariglio, N. \& Rechavi, G. (2010). apoB and apobec1, two genes key to lipid metabolism, are transcriptionally regulated by $\mathrm{p} 53$. Cell Cycle, Vol.9, No.18, (September 2010), pp.3761-3770, ISSN 1551-4005

Bernstein, A.; Forrester, L.; Reith, A.D.; Dubreuil, P. \& Rottapel, R. (1991). The murine W/ckit and Steel loci and the control of hematopoiesis. Semin Hematol, Vol.28, No.2, (April 1991), pp.138-142, ISSN 0037-1963

Besmer, P.; Manova, K.; Duttlinger, R.; Huang, E.J.; Packer, A.; Gyssler, C. \& Bachvarova, R.F. (1993). The kit-ligand (steel factor) and its receptor c-kit/W: pleiotropic roles in gametogenesis and melanogenesis. Dev Suppl, pp.125-137

Blasco, M.A.; Lee, H.W.; Hande, M.P.; Samper, E.; Lansdorp, P.M.; DePinho, R.A. \& Greider, C.W. (1997). Telomere shortening and tumor formation by mouse cells lacking telomerase RNA. Cell, Vol.91, No.1, (October 1997), pp.25-34, ISSN 0092-8674

Bowles, J.; Knight, D.; Smith, C.; Wilhelm, D.; Richman, J.; Mamiya, S.; Yashiro, K.; Chawengsaksophak, K.; Wilson, M.J.; Rossant, J.; Hamada, H. \& Koopman, P. (2006). Retinoid signaling determines germ cell fate in mice. Science, Vol.312, No.5773, (April 2006), pp.596-600, ISSN 1095-9203 
Brannan, C.I.; Bedell, M.A.; Resnick, J.L.; Eppig, J.J.; Handel, M.A.; Williams, D.E.; Lyman, S.D.; Donovan, P.J.; Jenkins, N.A. \& Copeland, N.G. (1992). Developmental abnormalities in Steel17H mice result from a splicing defect in the steel factor cytoplasmic tail. Genes Dev, Vol.6, No.10, (October 1992), pp.1832-1842, ISSN 08909369

Buetow, S.A. (1995). Epidemiology of testicular cancer. Epidemiol Rev, Vol.17, No.2, pp.433449, ISSN 0193-936X

Burtner, C.R. \& Kennedy, B.K. (2010). Progeria syndromes and ageing: what is the connection? Nat Rev Mol Cell Biol, Vol.11, No.8, (August 2010), pp.567-578, ISSN 1471-0080

Carson, W.E.; Haldar, S.; Baiocchi, R.A.; Croce, C.M. \& Caligiuri, M.A. (1994). The c-kit ligand suppresses apoptosis of human natural killer cells through the upregulation of bcl-2. Proc Natl Acad Sci U S A, Vol.91, No.16, (August 1994), pp.7553-7557, ISSN 0027-8424

Castren, M.; Tervonen, T.; Karkkainen, V.; Heinonen, S.; Castren, E.; Larsson, K.; Bakker, C.E.; Oostra, B.A. \& Akerman, K. (2005). Altered differentiation of neural stem cells in fragile X syndrome. Proc Natl Acad Sci U S A, Vol.102, No.49, (December 2005), pp.17834-17839, ISSN 0027-8424

Chao, C.H.; Chen, C.M.; Cheng, P.L.; Shih, J.W.; Tsou, A.P. \& Lee, Y.H. (2006). DDX3, a DEAD box RNA helicase with tumor growth-suppressive property and transcriptional regulation activity of the p21waf1/cip1 promoter, is a candidate tumor suppressor. Cancer Res, Vol.66, No.13, (July 2006), pp.6579-6588, ISSN 00085472

Chin, L.; Artandi, S.E.; Shen, Q.; Tam, A.; Lee, S.L.; Gottlieb, G.J.; Greider, C.W. \& DePinho, R.A. (1999). p53 deficiency rescues the adverse effects of telomere loss and cooperates with telomere dysfunction to accelerate carcinogenesis. Cell, Vol.97, No.4, (May 1999), pp.527-538, ISSN 0092-8674

Chipuk, J.E.; Kuwana, T.; Bouchier-Hayes, L.; Droin, N.M.; Newmeyer, D.D.; Schuler, M. \& Green, D.R. (2004). Direct activation of Bax by p53 mediates mitochondrial membrane permeabilization and apoptosis. Science, Vol.303, No.5660, (Februar 2004), pp.1010-1014, ISSN 1095-9203

Christoph, F.; Kempkensteffen, C.; Weikert, S.; Krause, H.; Schostak, M.; Miller, K. \& Schrader, M. (2007). Frequent epigenetic inactivation of p53 target genes in seminomatous and nonseminomatous germ cell tumors. Cancer Lett, Vol.247, No.1, (March 2007), pp.137-142, ISSN 0304-3835

Clark, J.M. \& Eddy, E.M. (1975). Fine structural observations on the origin and associations of primordial germ cells of the mouse. Dev Biol, Vol.47, No.1, (November 1975), pp.136-155, ISSN 0012-1606

Cook, M.S.; Coveney, D.; Batchvarov, I.; Nadeau, J.H. \& Capel, B. (2009). BAX-mediated cell death affects early germ cell loss and incidence of testicular teratomas in Dnd1(Ter/Ter) mice. Dev Biol, Vol.328, No.2, (April 2009), pp.377-383, ISSN 1095$564 X$

Cook, M.S.; Munger, S.C.; Nadeau, J.H. \& Capel, B. (2011). Regulation of male germ cell cycle arrest and differentiation by DND1 is modulated by genetic background. Development, Vol.138, No.1, (January 2011), pp.23-32, ISSN 1477-9129 
Copeland, N.G.; Gilbert, D.J.; Cho, B.C.; Donovan, P.J.; Jenkins, N.A.; Cosman, D.; Anderson, D.; Lyman, S.D. \& Williams, D.E. (1990). Mast cell growth factor maps near the steel locus on mouse chromosome 10 and is deleted in a number of steel alleles. Cell, Vol.63, No.1, (October 1990), pp.175-183, ISSN 0092-8674

Copeland, N.G.; Jenkins, N.A.; Gilbert, D.J.; Eppig, J.T.; Maltais, L.J.; Miller, J.C.; Dietrich, W.F.; Weaver, A.; Lincoln, S.E.; Steen, R.G. et al. (1993). A genetic linkage map of the mouse: current applications and future prospects. Science, Vol.262, No.5130, (October 1993), pp.57-66, ISSN 0036-8075

Crockford, G.P.; Linger, R.; Hockley, S.; Dudakia, D.; Johnson, L.; Huddart, R.; Tucker, K.; Friedlander, M.; Phillips, K.A.; Hogg, D.; Jewett, M.A.; Lohynska, R.; Lohynska, R.; Daugaard, G.; Richard, S.; Chompret, A.; Bonaiti-Pellie, C.; Heidenreich, A.; Albers, P.; Olah, E.; Geczi, L.; Bodrogi, I.; Ormiston, W.J.; Daly, P.A.; Guilford, P.; Fossa, S.D.; Heimdal, K.; Tjulandin, S.A.; Liubchenko, L.; Stoll, H.; Weber, W.; Forman, D.; Oliver, T.; Einhorn, L.; McMaster, M.; Kramer, J.; Greene, M.H.; Weber, B.L.; Nathanson, K.L.; Cortessis, V.; Easton, D.F.; Bishop, D.T.; Stratton, M.R. \& Rapley, E.A. (2006). Genome-wide linkage screen for testicular germ cell tumour susceptibility loci. Hum Mol Genet, Vol.15, No.3, (Februar 2006), pp.443-451, ISSN 0964-6906

Crowder, R.J.; Enomoto, H.; Yang, M.; Johnson, E.M., Jr. \& Milbrandt, J. (2004). Dok-6, a Novel p62 Dok family member, promotes Ret-mediated neurite outgrowth. J Biol Chem, Vol.279, No.40, (October 2004), pp.42072-42081, ISSN 0021-9258

Danchin, E.; Charmantier, A.; Champagne, F.A.; Mesoudi, A.; Pujol, B. \& Blanchet, S. (2011). Beyond DNA: integrating inclusive inheritance into an extended theory of evolution. Nat Rev Genet, Vol.12, No.7, (July 2011), pp.475-486, ISSN 1471-0064

de Rooij, D.G. (2001). Proliferation and differentiation of spermatogonial stem cells. Reproduction, Vol.121, No.3, (March 2001), pp.347-354, ISSN 1470-1626

Di Cristofano, A.; Pesce, B.; Cordon-Cardo, C. \& Pandolfi, P.P. (1998). Pten is essential for embryonic development and tumour suppression. Nat Genet, Vol.19, No.4, (August 1998), pp.348-355, ISSN 1061-4036

Dieckmann, K.P. \& Pichlmeier, U. (2004). Clinical epidemiology of testicular germ cell tumors. World J Urol, Vol.22, No.1, (April 2004), pp.2-14, ISSN 0724-4983

Donehower, L.A.; Harvey, M.; Slagle, B.L.; McArthur, M.J.; Montgomery, C.A., Jr.; Butel, J.S. \& Bradley, A. (1992). Mice deficient for p53 are developmentally normal but susceptible to spontaneous tumours. Nature, Vol.356, No.6366, (March 1992), pp.215-221, ISSN 0028-0836

Donehower, L.A.; Harvey, M.; Vogel, H.; McArthur, M.J.; Montgomery, C.A., Jr.; Park, S.H.; Thompson, T.; Ford, R.J. \& Bradley, A. (1995). Effects of genetic background on tumorigenesis in p53-deficient mice. Mol Carcinog, Vol.14, No.1, (September 1995), pp.16-22, ISSN 0899-1987

Donovan, P.J. (1998). The germ cell-the mother of all stem cells. Int. J. Dev. Biol., Vol.42, No.7, (1998), pp.1043-1050, ISSN 1696-3547

Duhl, D.M.; Stevens, M.E.; Vrieling, H.; Saxon, P.J.; Miller, M.W.; Epstein, C.J. \& Barsh, G.S. (1994). Pleiotropic effects of the mouse lethal yellow (Ay) mutation explained by deletion of a maternally expressed gene and the simultaneous production of agouti fusion RNAs. Development, Vol.120, No.6, (June 1994), pp.1695-1708, ISSN 0950-1991 
Ehrmann, I.E.; Ellis, P.S.; Mazeyrat, S.; Duthie, S.; Brockdorff, N.; Mattei, M.G.; Gavin, M.A.; Affara, N.A.; Brown, G.M.; Simpson, E.; Mitchell, M.J. \& Scott, D.M. (1998). Characterization of genes encoding translation initiation factor eIF-2gamma in mouse and human: sex chromosome localization, escape from X-inactivation and evolution. Hum Mol Genet, Vol.7, No.11, (October 1998), pp.1725-1737, ISSN 09646906

Fahrioglu, U.; Murphy, M.W.; Zarkower, D. \& Bardwell, V.J. (2007). mRNA expression analysis and the molecular basis of neonatal testis defects in Dmrt1 mutant mice. Sex Dev, Vol.1, No.1, (April 2007), pp.42-58, ISSN 1661-5433

Flanagan, J.G.; Chan, D.C. \& Leder, P. (1991). Transmembrane form of the kit ligand growth factor is determined by alternative splicing and is missing in the Sld mutant. Cell, Vol.64, No.5, (March 1991), pp.1025-1035, ISSN 0092-8674

Fu, Y.H.; Kuhl, D.P.; Pizzuti, A.; Pieretti, M.; Sutcliffe, J.S.; Richards, S.; Verkerk, A.J.; Holden, J.J.; Fenwick, R.G., Jr.; Warren, S.T. et al. (1991). Variation of the CGG repeat at the fragile $X$ site results in genetic instability: resolution of the Sherman paradox. Cell, Vol.67, No.6, (December 1991), pp.1047-1058, ISSN 0092-8674

Gilbert, D.; Rapley, E. \& Shipley, J. (2011). Testicular germ cell tumours: predisposition genes and the male germ cell niche. Nat Rev Cancer, Vol.11, No.4, (April 2011), pp.278-288, ISSN 1474-1768

Giwercman, A. \& Giwercman, Y.L. (2011). Environmental factors and testicular function. Best Pract Res Clin Endocrinol Metab, Vol.25, No.2, (April 2011), pp.391-402, ISSN 1532-1908

Grieco, M.; Santoro, M.; Berlingieri, M.T.; Melillo, R.M.; Donghi, R.; Bongarzone, I.; Pierotti, M.A.; Della Porta, G.; Fusco, A. \& Vecchio, G. (1990). PTC is a novel rearranged form of the ret proto-oncogene and is frequently detected in vivo in human thyroid papillary carcinomas. Cell, Vol.60, No.4, (Februar 1990), pp.557-563, ISSN 0092-8674

Griswold, M.D. (1995). Interactions between germ cells and Sertoli cells in the testis. Biol Reprod, Vol.52, No.2, (Februar 1995), pp.211-216, ISSN 0006-3363

Gustavson, K.H.; Gamstorp, I. \& Meurling, S. (1975). Bilateral teratoma of testis in two brothers with 47,XXY Klinefelter's syndrome. Clin Genet, Vol.8, No.1, (July 1975), pp.5-10, ISSN 0009-9163

Hammond, S.; Zhu, R.; Youngren, K.K.; Lam, J.; Anderson, P. \& Matin, A. (2007). Chromosome $\mathrm{X}$ modulates incidence of testicular germ cell tumors in Ter mice. Mamm Genome, Vol.18, No.12, (December 2007), pp.832-838, ISSN 0938-8990

Hayashi, K.; Chuva de Sousa Lopes, S.M.; Kaneda, M.; Tang, F.; Hajkova, P.; Lao, K.; O'Carroll, D.; Das, P.P.; Tarakhovsky, A.; Miska, E.A. \& Surani, M.A. (2008). MicroRNA biogenesis is required for mouse primordial germ cell development and spermatogenesis. PLoS One, Vol.3, No.3, (March 2008), pp.e1738, ISSN 1932-6203

He, X.; Ni, Y.; Wang, Y.; Romigh, T. \& Eng, C. (2011). Naturally occurring germline and tumor-associated mutations within the ATP-binding motifs of PTEN lead to oxidative damage of DNA associated with decreased nuclear p53. Hum Mol Genet, Vol.20, No.1, (January 2011), pp.80-89, ISSN 1460-2083

Heaney, J.D.; Lam, M.Y.; Michelson, M.V. \& Nadeau, J.H. (2008). Loss of the transmembrane but not the soluble kit ligand isoform increases testicular germ cell tumor susceptibility in mice. Cancer Res, Vol.68, No.13, (July 2008), pp.5193-5197, ISSN 1538-7445 
Heaney, J.D.; Michelson, M.V.; Youngren, K.K.; Lam, M.Y. \& Nadeau, J.H. (2009). Deletion of eIF2beta suppresses testicular cancer incidence and causes recessive lethality in agouti-yellow mice. Hum Mol Genet, Vol.18, No.8, (April 2009), pp.1395-1404, ISSN 1460-2083

Heiss, N.S.; Knight, S.W.; Vulliamy, T.J.; Klauck, S.M.; Wiemann, S.; Mason, P.J.; Poustka, A. \& Dokal, I. (1998). X-linked dyskeratosis congenita is caused by mutations in a highly conserved gene with putative nucleolar functions. Nat Genet, Vol.19, No.1, (May 1998), pp.32-38, ISSN 1061-4036

Hess, R.A.; Cooke, P.S.; Hofmann, M.C. \& Murphy, K.M. (2006). Mechanistic insights into the regulation of the spermatogonial stem cell niche. Cell Cycle, Vol.5, No.11, (June 2006), pp.1164-1170, ISSN 1551-4005

Huang, E.J.; Nocka, K.H.; Buck, J. \& Besmer, P. (1992). Differential expression and processing of two cell associated forms of the kit-ligand: KL-1 and KL-2. Mol Biol Cell, Vol.3, No.3, (March 1992), pp.349-362, ISSN 1059-1524

Hutter, A.M., Jr.; Lynch, J.L. \& Schnider, B.I. (1967). Malignant testicular tumors in brothers. JAMA, Vol.199, No.13, (March 1967), pp.155-156, ISSN 0098-7484

Ishii, T.; Kohu, K.; Yamada, S.; Ishidoya, S.; Kanto, S.; Fuji, H.; Moriya, T.; Satake, M. \& Arai, Y. (2007). Up-regulation of DNA-methyltransferase 3A expression is associated with hypomethylation of intron 25 in human testicular germ cell tumors. Tohoku J Exp Med, Vol.212, No.2, (June 2007), pp.177-190, ISSN 0040-8727

Jacks, T.; Remington, L.; Williams, B.O.; Schmitt, E.M.; Halachmi, S.; Bronson, R.T. \& Weinberg, R.A. (1994). Tumor spectrum analysis in p53-mutant mice. Curr Biol, Vol.4, No.1, (January 1994), pp.1-7, ISSN 0960-9822

Jady, B.E.; Bertrand, E. \& Kiss, T. (2004). Human telomerase RNA and box H/ACA scaRNAs share a common Cajal body-specific localization signal. J Cell Biol, Vol.164, No.5, (March 2004), pp.647-652, ISSN 0021-9525

Jin, P.; Zarnescu, D.C.; Ceman, S.; Nakamoto, M.; Mowrey, J.; Jongens, T.A.; Nelson, D.L.; Moses, K. \& Warren, S.T. (2004). Biochemical and genetic interaction between the fragile $\mathrm{X}$ mental retardation protein and the microRNA pathway. Nat Neurosci, Vol.7, No.2, (Februar 2004), pp.113-117, ISSN 1097-6256

Jordan, S.A.; Speed, R.M.; Bernex, F. \& Jackson, I.J. (1999). Deficiency of Trp53 rescues the male fertility defects of $\mathrm{Kit}(\mathrm{W}-\mathrm{v})$ mice but has no effect on the survival of melanocytes and mast cells. Dev Biol, Vol.215, No.1, (November 1999), pp.78-90, ISSN 0012-1606

Kalfa, N.; Paris, F.; Soyer-Gobillard, M.O.; Daures, J.P. \& Sultan, C. (2011). Prevalence of hypospadias in grandsons of women exposed to diethylstilbestrol during pregnancy: a multigenerational national cohort study. Fertil Steril, Vol.95, No.8, (June 2011), pp.2574-2577, ISSN 1556-5653

Kanetsky, P.A.; Mitra, N.; Vardhanabhuti, S.; Li, M.; Vaughn, D.J.; Letrero, R.; Ciosek, S.L.; Doody, D.R.; Smith, L.M.; Weaver, J.; Albano, A.; Chen, C.; Starr, J.R.; Rader, D.J.; Godwin, A.K.; Reilly, M.P.; Hakonarson, H.; Schwartz, S.M. \& Nathanson, K.L. (2009). Common variation in KITLG and at 5q31.3 predisposes to testicular germ cell cancer. Nat Genet, Vol.41, No.7, (July 2009), pp.811-815, ISSN 1546-1718

Kanetsky, P.A.; Mitra, N.; Vardhanabhuti, S.; Vaughn, D.J.; Li, M.; Ciosek, S.L.; Letrero, R.; D'Andrea, K.; Vaddi, M.; Doody, D.R.; Weaver, J.; Chen, C.; Starr, J.R.; Hakonarson, H.; Rader, D.J.; Godwin, A.K.; Reilly, M.P.; Schwartz, S.M. \& Nathanson, K.L. 
(2011). A second independent locus within DMRT1 is associated with testicular germ cell tumor susceptibility. Hum Mol Genet, Vol.20, No.15, (August 2011), pp.3109-3117, ISSN 1460-2083

Karl, J. \& Capel, B. (1998). Sertoli cells of the mouse testis originate from the coelomic epithelium. Dev Biol, Vol.203, No.2, (November 1998), pp.323-333, ISSN 0012-1606

Kedde, M.; Strasser, M.J.; Boldajipour, B.; Oude Vrielink, J.A.; Slanchev, K.; le Sage, C.; Nagel, R.; Voorhoeve, P.M.; van Duijse, J.; Orom, U.A.; Lund, A.H.; Perrakis, A.; Raz, E. \& Agami, R. (2007). RNA-binding protein Dnd1 inhibits microRNA access to target mRNA. Cell, Vol.131, No.7, (December 2007), pp.1273-1286, ISSN 00928674

Kimura, T.; Suzuki, A.; Fujita, Y.; Yomogida, K.; Lomeli, H.; Asada, N.; Ikeuchi, M.; Nagy, A.; Mak, T.W. \& Nakano, T. (2003). Conditional loss of PTEN leads to testicular teratoma and enhances embryonic germ cell production. Development, Vol.130, No.8, (April 2003), pp.1691-1700, ISSN 0950-1991

Kissel, H.; Timokhina, I.; Hardy, M.P.; Rothschild, G.; Tajima, Y.; Soares, V.; Angeles, M.; Whitlow, S.R.; Manova, K. \& Besmer, P. (2000). Point mutation in kit receptor tyrosine kinase reveals essential roles for kit signaling in spermatogenesis and oogenesis without affecting other kit responses. EMBO J, Vol.19, No.6, (March 2000), pp.1312-1326, ISSN 0261-4189

Koubova, J.; Menke, D.B.; Zhou, Q.; Capel, B.; Griswold, M.D. \& Page, D.C. (2006). Retinoic acid regulates sex-specific timing of meiotic initiation in mice. Proc Natl Acad Sci $U$ $S$ A, Vol.103, No.8, (Februar 2006), pp.2474-2479, ISSN 0027-8424

Kouprina, N.; Mullokandov, M.; Rogozin, I.B.; Collins, N.K.; Solomon, G.; Otstot, J.; Risinger, J.I.; Koonin, E.V.; Barrett, J.C. \& Larionov, V. (2004). The SPANX gene family of cancer/testis-specific antigens: rapid evolution and amplification in African great apes and hominids. Proc Natl Acad Sci U S A, Vol.101, No.9, (March 2004), pp.3077-3082, ISSN 0027-8424

Krentz, A.D.; Murphy, M.W.; Kim, S.; Cook, M.S.; Capel, B.; Zhu, R.; Matin, A.; Sarver, A.L.; Parker, K.L.; Griswold, M.D.; Looijenga, L.H.; Bardwell, V.J. \& Zarkower, D. (2009). The DM domain protein DMRT1 is a dose-sensitive regulator of fetal germ cell proliferation and pluripotency. Proc Natl Acad Sci U S A, Vol.106, No.52, (December 2009), pp.22323-22328, ISSN 1091-6490

Krishna, S.; Low, I.C. \& Pervaiz, S. (2011). Regulation of mitochondrial metabolism: yet another facet in the biology of the oncoprotein Bcl-2. Biochem J, Vol.435, No.3, (May 2011), pp.545-551, ISSN 1470-8728

Lam, M.Y.; Youngren, K.K. \& Nadeau, J.H. (2004). Enhancers and suppressors of testicular cancer susceptibility in single- and double-mutant mice. Genetics, Vol.166, No.2, (Februar 2004), pp.925-933, ISSN 0016-6731

Lam, M.Y.; Heaney, J.D.; Youngren, K.K.; Kawasoe, J.H. \& Nadeau, J.H. (2007). Transgenerational epistasis between Dnd1Ter and other modifier genes controls susceptibility to testicular germ cell tumors. Hum Mol Genet, Vol.16, No.18, (September 2007), pp.2233-2240, ISSN 0964-6906

Lambrot, R.; Coffigny, H.; Pairault, C.; Lecureuil, C.; Frydman, R.; Habert, R. \& RouillerFabre, V. (2007). High radiosensitivity of germ cells in human male fetus. J Clin Endocrinol Metab, Vol.92, No.7, (July 2007), pp.2632-2639, ISSN 0021-972X 
Lau, M.T.; Klausen, C. \& Leung, P.C. (2011). E-cadherin inhibits tumor cell growth by suppressing PI3K/Akt signaling via beta-catenin-Egr1-mediated PTEN expression. Oncogene, Vol.30, No.24, (June 2011), pp.2753-2766, ISSN 1476-5594

Lau, Y.F. (1999). Gonadoblastoma, testicular and prostate cancers, and the TSPY gene. Am J Hum Genet, Vol.64, No.4, (April 1999), pp.921-927, ISSN 0002-9297

LeBron, C.; Pal, P.; Brait, M.; Dasgupta, S.; Guerrero-Preston, R.; Looijenga, L.H.; Kowalski, J.; Netto, G. \& Hoque, M.O. (2011). Genome-wide analysis of genetic alterations in testicular primary seminoma using high resolution single nucleotide polymorphism arrays. Genomics, Vol.97, No.6, (June 2011), pp.341-349, ISSN 10898646

Lee, H.W.; Blasco, M.A.; Gottlieb, G.J.; Horner, J.W., 2nd; Greider, C.W. \& DePinho, R.A. (1998). Essential role of mouse telomerase in highly proliferative organs. Nature, Vol.392, No.6676, (April 1998), pp.569-574, ISSN 0028-0836

Leeksma, O.C.; Van Achterberg, T.A.; Tsumura, Y.; Toshima, J.; Eldering, E.; Kroes, W.G.; Mellink, C.; Spaargaren, M.; Mizuno, K.; Pannekoek, H. \& de Vries, C.J. (2002). Human sprouty 4 , a new ras antagonist on $5 q 31$, interacts with the dual specificity kinase TESK1. Eur J Biochem, Vol.269, No.10, (May 2002), pp.2546-2556, ISSN 00142956

Li, H.; MacLean, G.; Cameron, D.; Clagett-Dame, M. \& Petkovich, M. (2009). Cyp26b1 expression in murine Sertoli cells is required to maintain male germ cells in an undifferentiated state during embryogenesis. PLoS One, Vol.4, No.10, (October 2009), pp.e7501, ISSN 1932-6203

Lin, T.; Chao, C.; Saito, S.; Mazur, S.J.; Murphy, M.E.; Appella, E. \& Xu, Y. (2005). p53 induces differentiation of mouse embryonic stem cells by suppressing Nanog expression. Nat Cell Biol, Vol.7, No.2, (Februar 2005), pp.165-171, ISSN 1465-7392

Liu, D.; Ou, L.; Clemenson, G.D., Jr.; Chao, C.; Lutske, M.E.; Zambetti, G.P.; Gage, F.H. \& $\mathrm{Xu}, \mathrm{Y}$. (2010). Puma is required for p53-induced depletion of adult stem cells. Nat Cell Biol, Vol.12, No.10, (October 2010), pp.993-998, ISSN 1476-4679

Liu, Z.; Luyten, I.; Bottomley, M.J.; Messias, A.C.; Houngninou-Molango, S.; Sprangers, R.; Zanier, K.; Kramer, A. \& Sattler, M. (2001). Structural basis for recognition of the intron branch site RNA by splicing factor 1. Science, Vol.294, No.5544, (November 2001), pp.1098-1102, ISSN 0036-8075

Lobo, G.P.; Waite, K.A.; Planchon, S.M.; Romigh, T.; Nassif, N.T. \& Eng, C. (2009). Germline and somatic cancer-associated mutations in the ATP-binding motifs of PTEN influence its subcellular localization and tumor suppressive function. Hum Mol Genet, Vol.18, No.15, (August 2009), pp.2851-2862, ISSN 1460-2083

Looijenga, L.H.; de Leeuw, H.; van Oorschot, M.; van Gurp, R.J.; Stoop, H.; Gillis, A.J.; de Gouveia Brazao, C.A.; Weber, R.F.; Kirkels, W.J.; van Dijk, T.; von Lindern, M.; Valk, P.; Lajos, G.; Olah, E.; Nesland, J.M.; Fossa, S.D. \& Oosterhuis, J.W. (2003). Stem cell factor receptor (c-KIT) codon 816 mutations predict development of bilateral testicular germ-cell tumors. Cancer Res, Vol.63, No.22, (November 2003), pp.7674-7678, ISSN 0008-5472

MacLean, G.; Li, H.; Metzger, D.; Chambon, P. \& Petkovich, M. (2007). Apoptotic extinction of germ cells in testes of Cyp26b1 knockout mice. Endocrinology, Vol.148, No.10, (October 2007), pp.4560-4567, ISSN 0013-7227 
Mahmoudi, S.; Henriksson, S.; Corcoran, M.; Mendez-Vidal, C.; Wiman, K.G. \& Farnebo, M. (2009). Wrap53, a natural p53 antisense transcript required for p53 induction upon DNA damage. Mol Cell, Vol.33, No.4, (Februar 2009), pp.462-471, ISSN 1097-4164

Malkin, D.; Li, F.P.; Strong, L.C.; Fraumeni, J.F.Jr.; Nelson, C.E.; Kim, D.H.; Kassel, J.; Gryka, M.A.; Bischoff, F.Z.; Tainsky, M.A. \& Friend, S.H. (1990). Germ line p53 mutations in a familial syndrome of breast cancer, sarcomas, and other neoplasms. Science, Vol.250, No.4985, (September 1990), pp.1233-1238, ISSN 0036-8075

Manova, K.; Nocka, K.; Besmer, P. \& Bachvarova, R.F. (1990). Gonadal expression of c-kit encoded at the W locus of the mouse. Development, Vol.110, No.4, (December 1990), pp.1057-1069, ISSN 0950-1991

Marrone, A.; Walne, A.; Tamary, H.; Masunari, Y.; Kirwan, M.; Beswick, R.; Vulliamy, T. \& Dokal, I. (2007). Telomerase reverse-transcriptase homozygous mutations in autosomal recessive dyskeratosis congenita and Hoyeraal-Hreidarsson syndrome. Blood, Vol.110, No.13, (December 2007), pp.4198-4205, ISSN 0006-4971

Matin, A.; Collin, G.B.; Asada, Y.; Varnum, D.; Martone, D.L. \& Nadeau, J.H. (1998). Simple sequence length polymorphisms (SSLPs) that distinguish MOLF/Ei and 129/Sv inbred strains of laboratory mice. Mamm Genome, Vol.9, No.8, (August 1998), pp.668-670, ISSN 0938-8990

Matin, A.; Collin, G.B.; Asada, Y.; Varnum, D. \& Nadeau, J.H. (1999). Susceptibility to testicular germ-cell tumours in a 129.MOLF-Chr 19 chromosome substitution strain. Nat Genet, Vol.23, No.2, (October 1999), pp.237-240, ISSN 1061-4036

Matson, C.K.; Murphy, M.W.; Griswold, M.D.; Yoshida, S.; Bardwell, V.J. \& Zarkower, D. (2010). The mammalian doublesex homolog DMRT1 is a transcriptional gatekeeper that controls the mitosis versus meiosis decision in male germ cells. Dev Cell, Vol.19, No.4, (October 2010), pp.612-624, ISSN 1878-1551

Matsui, Y.; Zsebo, K.M. \& Hogan, B.L. (1990). Embryonic expression of a haematopoietic growth factor encoded by the Sl locus and the ligand for c-kit. Nature, Vol.347, No.6294, (October 1990), pp.667-669, ISSN 0028-0836

Mauduit, C.; Hamamah, S. \& Benahmed, M. (1999). Stem cell factor/c-kit system in spermatogenesis. Hum Reprod Update, Vol.5, No.5, (October 1999), pp.535-545, ISSN $1355-4786$

McConkie-Rosell, A.; Lachiewicz, A.M.; Spiridigliozzi, G.A.; Tarleton, J.; Schoenwald, S.; Phelan, M.C.; Goonewardena, P.; Ding, X. \& Brown, W.T. (1993). Evidence that methylation of the FMR-I locus is responsible for variable phenotypic expression of the fragile X syndrome. Am J Hum Genet, Vol.53, No.4, (October 1993), pp.800-809, ISSN 0002-9297

McCoshen, J.A. \& McCallion, D.J. (1975). A study of the primordial germ cells during their migratory phase in Steel mutant mice. Experientia, Vol.31, No.5, (May 1975), pp.589590, ISSN 0014-4754

McGlynn, K.A.; Devesa, S.S.; Graubard, B.I. \& Castle, P.E. (2005). Increasing incidence of testicular germ cell tumors among black men in the United States. J Clin Oncol, Vol.23, No.24, (August 2005), pp.5757-5761, ISSN 0732-183X

Michalak, E.; Villunger, A.; Erlacher, M. \& Strasser, A. (2005). Death squads enlisted by the tumour suppressor p53. Biochem Biophys Res Commun, Vol.331, No.3, (June 2005), pp.786-798, ISSN 0006-291X 
Michaud, E.J.; Bultman, S.J.; Klebig, M.L.; van Vugt, M.J.; Stubbs, L.J.; Russell, L.B. \& Woychik, R.P. (1994). A molecular model for the genetic and phenotypic characteristics of the mouse lethal yellow (Ay) mutation. Proc Natl Acad Sci U S A, Vol.91, No.7, (March 1994), pp.2562-2566, ISSN 0027-8424

Mieno, M.; Udono, H.; Ikegami, S.; Tada, N.; Shiku, H. \& Nakayama, E. (1989). Blocking of cytotoxic T-cell function of MOLF/Ei mice by anti-Ly 35.1 monoclonal antibody. Immunology, Vol.68, No.3, (November 1989), pp.431-433, ISSN 0019-2805

Minami, K.; Chano, T.; Kawakami, T.; Ushida, H.; Kushima, R.; Okabe, H.; Okada, Y. \& Okamoto, K. (2010). DNMT3L is a novel marker and is essential for the growth of human embryonal carcinoma. Clin Cancer Res, Vol.16, No.10, (May 2010), pp.27512759, ISSN 1078-0432

Mithraprabhu, S. \& Loveland, K.L. (2009). Control of KIT signalling in male germ cells: what can we learn from other systems? Reproduction, Vol.138, No.5, (November 2009), pp.743-757, ISSN 1741-7899

Molyneaux, K.A.; Stallock, J.; Schaible, K. \& Wylie, C. (2001). Time-lapse analysis of living mouse germ cell migration. Dev Biol, Vol.240, No.2, (December 2001), pp.488-498, ISSN 0012-1606

Moore, F.L.; Jaruzelska, J.; Fox, M.S.; Urano, J.; Firpo, M.T.; Turek, P.J.; Dorfman, D.M. \& Pera, R.A. (2003). Human Pumilio-2 is expressed in embryonic stem cells and germ cells and interacts with DAZ (Deleted in AZoospermia) and DAZ-like proteins. Proc Natl Acad Sci U S A, Vol.100, No.2, (January 2003), pp.538-543, ISSN 0027-8424

Muller, A.J.; Teresky, A.K. \& Levine, A.J. (2000). A male germ cell tumor-susceptibilitydetermining locus, pgct1, identified on murine chromosome 13. Proc Natl Acad Sci U S A, Vol.97, No.15, (July 2000), pp.8421-8426, ISSN 0027-8424

Murphy, M.W.; Sarver, A.L.; Rice, D.; Hatzi, K.; Ye, K.; Melnick, A.; Heckert, L.L.; Zarkower, D. \& Bardwell, V.J. (2010). Genome-wide analysis of DNA binding and transcriptional regulation by the mammalian Doublesex homolog DMRT1 in the juvenile testis. Proc Natl Acad Sci U S A, Vol.107, No.30, (July 2010), pp.13360-13365, ISSN 1091-6490

Murty, V.V.; Houldsworth, J.; Baldwin, S.; Reuter, V.; Hunziker, W.; Besmer, P.; Bosl, G. \& Chaganti, R.S. (1992). Allelic deletions in the long arm of chromosome 12 identify sites of candidate tumor suppressor genes in male germ cell tumors. Proc Natl Acad Sci U S A, Vol.89, No.22, (November 1992), pp.11006-11010, ISSN 0027-8424

Murty, V.V.; Bosl, G.J.; Houldsworth, J.; Meyers, M.; Mukherjee, A.B.; Reuter, V. \& Chaganti, R.S. (1994). Allelic loss and somatic differentiation in human male germ cell tumors. Oncogene, Vol.9, No.8, (August 1994), pp.2245-2251, ISSN 0950-9232

Myers, M.P.; Stolarov, J.P.; Eng, C.; Li, J.; Wang, S.I.; Wigler, M.H.; Parsons, R. \& Tonks, N.K. (1997). P-TEN, the tumor suppressor from human chromosome 10q23, is a dualspecificity phosphatase. Proc Natl Acad Sci U S A, Vol.94, No.17, (August 1997), pp.9052-9057, ISSN 0027-8424

Nagano, R.; Tabata, S.; Nakanishi, Y.; Ohsako, S.; Kurohmaru, M. \& Hayashi, Y. (2000). Reproliferation and relocation of mouse male germ cells (gonocytes) during prespermatogenesis. Anat Rec, Vol.258, No.2, (Februar 2000), pp.210-220, ISSN 0003-276X

Nathanson, K.L.; Kanetsky, P.A.; Hawes, R.; Vaughn, D.J.; Letrero, R.; Tucker, K.; Friedlander, M.; Phillips, K.A.; Hogg, D.; Jewett, M.A.; Lohynska, R.; Daugaard, G.; 
Richard, S.; Chompret, A.; Bonaiti-Pellie, C.; Heidenreich, A. et al. (2005). The Y deletion gr/gr and susceptibility to testicular germ cell tumor. Am J Hum Genet, Vol.77, No.6, (December 2005), pp.1034-1043, ISSN 0002-9297

Nelson, K.M. \& Weiss, G.J. (2008). MicroRNAs and cancer: past, present, and potential future. Mol Cancer Ther, Vol.7, No.12, (December 2008), pp.3655-3660, ISSN 15357163

Nelson, V.R. \& Nadeau J.H. (2010) Transgenerational genetic effects. Epigenomics, Vol.2, No.6, pp.797-806, ISSN 1750-1911

Nocka, K.; Buck, J.; Levi, E. \& Besmer, P. (1990). Candidate ligand for the c-kit transmembrane kinase receptor: KL, a fibroblast derived growth factor stimulates mast cells and erythroid progenitors. EMBO J, Vol.9, No.10, (October 1990), pp.3287-3294, ISSN 0261-4189

Noguchi, T. \& Noguchi, M. (1985). A recessive mutation (ter) causing germ cell deficiency and a high incidence of congenital testicular teratomas in 129/Sv-ter mice. J Natl Cancer Inst, Vol.75, No.2, (August 1985), pp.385-392, ISSN 0027-8874

Parker, R. \& Sheth, U. (2007). P bodies and the control of mRNA translation and degradation. Mol Cell, Vol.25, No.5, (March 2007), pp.635-646, ISSN 1097-2765

Patriotis, C.; Makris, A.; Chernoff, J. \& Tsichlis, P.N. (1994). Tpl-2 acts in concert with Ras and Raf-1 to activate mitogen-activated protein kinase. Proc Natl Acad Sci U S A, Vol.91, No.21, (October 1994), pp.9755-9759, ISSN 0027-8424

Peltomaki, P.; Halme, A. \& de la Chapelle, A. (1990). Human testicular cancer. Changes in autosomal dosage. Cancer Genet Cytogenet, Vol.48, No.1, (August 1990), pp.1-12, ISSN 0165-4608

Peng, H.Q.; Bailey, D.; Bronson, D.; Goss, P.E. \& Hogg, D. (1995). Loss of heterozygosity of tumor suppressor genes in testis cancer. Cancer Res, Vol.55, No.13, (July 1995), pp.2871-2875, ISSN 0008-5472

Pesce, M.; Farrace, M.G.; Piacentini, M.; Dolci, S. \& De Felici, M. (1993). Stem cell factor and leukemia inhibitory factor promote primordial germ cell survival by suppressing programmed cell death (apoptosis). Development, Vol.118, No.4, (August 1993), pp.1089-1094, ISSN 0950-1991

Rapley, E.A.; Crockford, G.P.; Teare, D.; Biggs, P.; Seal, S.; Barfoot, R.; Edwards, S.; Hamoudi, R.; Heimdal, K.; Fossa, S.D.; Tucker, K.; Donald, J.; Collins, F.; Friedlander, M.; Hogg, D.; Goss, P.; Heidenreich, A.; Olah, E.; Geczi, L.; Bodrogi, I.; Ormiston, W.J.; Daly, P.A.; Oosterhuis, J.W.; Gillis, A.J.; Looijenga, L.H.; Guilford, P.; Fossa, S.D.; Heimdal, K.; Tjulandin, S.A.; Liubchenko, L.; Stoll, H.; Weber, W.; Rudd, M.; Huddart, R.; Crockford, G.P.; Forman, D.; Oliver, D.T.; Einhorn, L.; Weber, B.L.; Kramer, J.; McMaster, M.; Greene, M.H.; Pike, M.; Cortessis, V.; Chen, C.; Schwartz, S.M.; Bishop, D.T.; Easton, D.F.; Stratton, M.R. \& Rapley, E.A. (2000). Localization to Xq27 of a susceptibility gene for testicular germ-cell tumours. Nat Genet, Vol.24, No.2, (Februar 2000), pp.197-200, ISSN 1061-4036

Rapley, E.A.; Turnbull, C.; Al Olama, A.A.; Dermitzakis, E.T.; Linger, R.; Huddart, R.A.; Renwick, A.; Hughes, D.; Hines, S.; Seal, S.; Morrison, J.; Nsengimana, J.; Deloukas, P.; Rahman, N.; Bishop, D.T.; Easton, D.F. \& Stratton, M.R. (2009). A genome-wide association study of testicular germ cell tumor. Nat Genet, Vol.41, No.7, (July 2009), pp.807-810, ISSN 1546-1718 
Raymond, C.S.; Kettlewell, J.R.; Hirsch, B.; Bardwell, V.J. \& Zarkower, D. (1999). Expression of Dmrt1 in the genital ridge of mouse and chicken embryos suggests a role in vertebrate sexual development. Dev Biol, Vol.215, No.2, (November 1999), pp.208220, ISSN 0012-1606

Raymond, C.S.; Murphy, M.W.; O'Sullivan, M.G.; Bardwell, V.J. \& Zarkower, D. (2000). Dmrt1, a gene related to worm and fly sexual regulators, is required for mammalian testis differentiation. Genes Dev, Vol.14, No.20, (October 2000), pp.25872595, ISSN 0890-9369

Rivers, E.N. \& Hamilton, D.W. (1986). Morphologic analysis of spontaneous teratocarcinogenesis in developing testes of strain 129/Sv-ter mice. Am J Pathol, Vol.124, No.2, (August 1986), pp.263-280, ISSN 0002-9440

Rossi, P.; Albanesi, C.; Grimaldi, P. \& Geremia, R. (1991). Expression of the mRNA for the ligand of c-kit in mouse Sertoli cells. Biochem Biophys Res Commun, Vol.176, No.2, (April 1991), pp.910-914, ISSN 0006-291X

Rotter, V.; Schwartz, D.; Almon, E.; Goldfinger, N.; Kapon, A.; Meshorer, A.; Donehower, L.A. \& Levine, A.J. (1993). Mice with reduced levels of p53 protein exhibit the testicular giant-cell degenerative syndrome. Proc Natl Acad Sci U S A, Vol.90, No.19, (October 1993), pp.9075-9079, ISSN 0027-8424

Saal, L.H.; Gruvberger-Saal, S.K.; Persson, C.; Lovgren, K.; Jumppanen, M.; Staaf, J.; Jonsson, G.; Pires, M.M.; Maurer, M.; Holm, K.; Koujak, S.; Subramaniyam, S.; VallonChristersson, J.; Olsson, H.; Su, T.; Memeo, L.; Ludwig, T. et al. (2008). Recurrent gross mutations of the PTEN tumor suppressor gene in breast cancers with deficient DSB repair. Nat Genet, Vol.40, No.1, (January 2008), pp.102-107, ISSN 15461718

Salemi, M.; Calogero, A.E.; Castiglione, R.; Tricoli, D.; Asero, P.; Rosa, R.; Rappazzo, G. \& Vicari, E. (2006). Expression of SpanX proteins in normal testes and in testicular germ cell tumours. Int J Androl, Vol.29, No.2, (April 2006), pp.368-373, ISSN 01056263

Sarre, T.F. (1989). The phosphorylation of eukaryotic initiation factor 2: a principle of translational control in mammalian cells. Biosystems, Vol.22, No.4, pp.311-325, ISSN 0303-2647

Sasaki, H. \& Matsui, Y. (2008). Epigenetic events in mammalian germ-cell development: reprogramming and beyond. Nat Rev Genet, Vol.9, No.2, (Februar 2008), pp.129-140, ISSN 1471-0064

Satge, D.; Sasco, A.J.; Cure, H.; Leduc, B.; Sommelet, D. \& Vekemans, M.J. (1997). An excess of testicular germ cell tumors in Down's syndrome: three case reports and a review of the literature. Cancer, Vol.80, No.5, (September 1997), pp.929-935, ISSN 0008$543 X$

Schwartz, D.; Goldfinger, N. \& Rotter, V. (1993). Expression of p53 protein in spermatogenesis is confined to the tetraploid pachytene primary spermatocytes. Oncogene, Vol.8, No.6, (June 1993), pp.1487-1494, ISSN 0950-9232

Seydoux, G. \& Braun, R.E. (2006). Pathway to totipotency: lessons from germ cells. Cell, Vol.127, No.5, (December 2006), pp.891-904, ISSN 0092-8674

Shen, W.H.; Balajee, A.S.; Wang, J.; Wu, H.; Eng, C.; Pandolfi, P.P. \& Yin, Y. (2007). Essential role for nuclear PTEN in maintaining chromosomal integrity. Cell, Vol.128, No.1, (January 2007), pp.157-170, ISSN 0092-8674 
Shimizu, S.; Narita, M. \& Tsujimoto, Y. (1999). Bcl-2 family proteins regulate the release of apoptogenic cytochrome c by the mitochondrial channel VDAC. Nature, Vol.399, No.6735, (June 1999), pp.483-487, ISSN 0028-0836

Skakkebaek, N.E. (1972). Abnormal morphology of germ cells in two infertile men. Acta Pathol Microbiol Scand A, Vol.80, No.3, pp.374-378, ISSN 0365-4184

Skotheim, R.I.; Kraggerud, S.M.; Fossa, S.D.; Stenwig, A.E.; Gedde-Dahl, T., Jr.; Danielsen, H.E.; Jakobsen, K.S. \& Lothe, R.A. (2001). Familial/bilateral and sporadic testicular germ cell tumors show frequent genetic changes at loci with suggestive linkage evidence. Neoplasia, Vol.3, No.3, (June 2001), pp.196-203, ISSN 1522-8002

Soh, L.T.; Ang, P.T. \& Lim-Tan, S.K. (1992). Embryonal carcinoma arising in Turner's syndrome. Ann Acad Med Singapore, Vol.21, No.3, (May 1992), pp.386-389, ISSN 0304-4602

Stallock, J.; Molyneaux, K.; Schaible, K.; Knudson, C.M. \& Wylie, C. (2003). The proapoptotic gene Bax is required for the death of ectopic primordial germ cells during their migration in the mouse embryo. Development, Vol.130, No.26, (December 2003), pp.6589-6597, ISSN 0950-1991

Stevens, L.C. \& Little, C.C. (1954). Spontaneous Testicular Teratomas in an Inbred Strain of Mice. Proc Natl Acad Sci U S A, Vol.40, No.11, (November 1954), pp.1080-1087, ISSN 0027-8424

Stevens, L.C. (1967). Origin of testicular teratomas from primordial germ cells in mice. J Natl Cancer Inst, Vol.38, No.4, (April 1967), pp.549-552, ISSN 0027-8874

Stevens, L.C. (1973). A new inbred subline of mice (129-terSv) with a high incidence of spontaneous congenital testicular teratomas. J Natl Cancer Inst, Vol.50, No.1, (January 1973), pp.235-242, ISSN 0027-8874

Su, X.; Chakravarti, D.; Cho, M.S.; Liu, L.; Gi, Y.J.; Lin, Y.L.; Leung, M.L.; El-Naggar, A.; Creighton, C.J.; Suraokar, M.B.; Wistuba, I. \& Flores, E.R. (2010). TAp63 suppresses metastasis through coordinate regulation of Dicer and miRNAs. Nature, Vol.467, No.7318, (October 2010), pp.986-990, ISSN 1476-4687

Suzuki, A. \& Saga, Y. (2008). Nanos2 suppresses meiosis and promotes male germ cell differentiation. Genes Dev, Vol.22, No.4, (Februar 2008), pp.430-435, ISSN 0890-9369

Suzuki, K. \& Matsubara, H. (2011). Recent advances in p53 research and cancer treatment. J Biomed Biotechnol, Vol.2011, (July 2011), pp. 978312- 978319, ISSN 1110-7251

Swerdlow, A.J.; De Stavola, B.L.; Swanwick, M.A.; Mangtani, P. \& Maconochie, N.E. (1999). Risk factors for testicular cancer: a case-control study in twins. Br J Cancer, Vol.80, No.7, (June 1999), pp.1098-1102, ISSN 0007-0920

Tajima, Y.; Sakamaki, K.; Watanabe, D.; Koshimizu, U.; Matsuzawa, T. \& Nishimune, Y. (1991). Steel-Dickie (Sld) mutation affects both maintenance and differentiation of testicular germ cells in mice. J Reprod Fertil, Vol.91, No.2, (March 1991), pp.441-449, ISSN 0022-4251

Tang, Y. \& Eng, C. (2006). p53 down-regulates phosphatase and tensin homologue deleted on chromosome 10 protein stability partially through caspase-mediated degradation in cells with proteasome dysfunction. Cancer Res, Vol.66, No.12, (June 2006), pp.6139-6148, ISSN 0008-5472

Tokuzawa, Y.; Kaiho, E.; Maruyama, M.; Takahashi, K.; Mitsui, K.; Maeda, M.; Niwa, H. \& Yamanaka, S. (2003). Fbx15 is a novel target of Oct3/4 but is dispensable for 
embryonic stem cell self-renewal and mouse development. Mol Cell Biol, Vol.23, No.8, (April 2003), pp.2699-2708, ISSN 0270-7306

Tsuda, M.; Sasaoka, Y.; Kiso, M.; Abe, K.; Haraguchi, S.; Kobayashi, S. \& Saga, Y. (2003). Conserved role of nanos proteins in germ cell development. Science, Vol.301, No.5637, (August 2003), pp.1239-1241, ISSN 1095-9203

Turnbull, C.; Rapley, E.A.; Seal, S.; Pernet, D.; Renwick, A.; Hughes, D.; Ricketts, M.; Linger, R.; Nsengimana, J.; Deloukas, P.; Huddart, R.A.; Bishop, D.T.; Easton, D.F.; Stratton, M.R. \& Rahman, N. (2010). Variants near DMRT1, TERT and ATF7IP are associated with testicular germ cell cancer. Nat Genet, Vol.42, No.7, (July 2010), pp.604-607, ISSN 1546-1718

Ushida, H.; Kawakami, T.; Minami, K.; Chano, T.; Okabe, H.; Okada, Y. \& Okamoto, K. (2011). Methylation profile of DNA repetitive elements in human testicular germ cell tumor. Mol Carcinog, (August 2011), ISSN 1098-2744

Venteicher, A.S.; Abreu, E.B.; Meng, Z.; McCann, K.E.; Terns, R.M.; Veenstra, T.D.; Terns, M.P. \& Artandi, S.E. (2009). A human telomerase holoenzyme protein required for Cajal body localization and telomere synthesis. Science, Vol.323, No.5914, (January 2009), pp.644-648, ISSN 1095-9203

Vulliamy, T.; Marrone, A.; Goldman, F.; Dearlove, A.; Bessler, M.; Mason, P.J. \& Dokal, I. (2001). The RNA component of telomerase is mutated in autosomal dominant dyskeratosis congenita. Nature, Vol.413, No.6854, (September 2001), pp.432-435, ISSN 0028-0836

Weaver, B.A.; Silk, A.D.; Montagna, C.; Verdier-Pinard, P. \& Cleveland, D.W. (2007). Aneuploidy acts both oncogenically and as a tumor suppressor. Cancer Cell, Vol.11, No.1, (January 2007), pp.25-36, ISSN 1535-6108

Weidinger, G.; Stebler, J.; Slanchev, K.; Dumstrei, K.; Wise, C.; Lovell-Badge, R.; Thisse, C.; Thisse, B. \& Raz, E. (2003). dead end, a novel vertebrate germ plasm component, is required for zebrafish primordial germ cell migration and survival. Curr Biol, Vol.13, No.16, (August 2003), pp.1429-1434, ISSN 0960-9822

Wendel, H.G.; De Stanchina, E.; Fridman, J.S.; Malina, A.; Ray, S.; Kogan, S.; Cordon-Cardo, C.; Pelletier, J. \& Lowe, S.W. (2004). Survival signalling by Akt and eIF4E in oncogenesis and cancer therapy. Nature, Vol.428, No.6980, (March 2004), pp.332337, ISSN 1476-4687

Westbrook, V.A.; Schoppee, P.D.; Diekman, A.B.; Klotz, K.L.; Allietta, M.; Hogan, K.T.; Slingluff, C.L.; Patterson, J.W.; Frierson, H.F.; Irvin, W.P., Jr.; Flickinger, C.J.; Coppola, M.A. \& Herr, J.C. (2004). Genomic organization, incidence, and localization of the SPAN-x family of cancer-testis antigens in melanoma tumors and cell lines. Clin Cancer Res, Vol.10, No.1 Pt 1, (January 2004), pp.101-112, ISSN 1078-0432

$\mathrm{Xu}, \mathrm{Y}$. (2003). Regulation of p53 responses by post-translational modifications. Cell Death Differ, Vol.10, No.4, (April 2003), pp.400-403, ISSN 1350-9047

Yanagiya, A.; Delbes, G.; Svitkin, Y.V.; Robaire, B. \& Sonenberg, N. (2010). The poly(A)binding protein partner Paip2a controls translation during late spermiogenesis in mice. J Clin Invest, Vol.120, No.9, (September 2010), pp.3389-3400, ISSN 1558-8238

Yoshinaga, K.; Nishikawa, S.; Ogawa, M.; Hayashi, S.; Kunisada, T. \& Fujimoto, T. (1991). Role of c-kit in mouse spermatogenesis: identification of spermatogonia as a 
specific site of c-kit expression and function. Development, Vol.113, No.2, (October 1991), pp.689-699, ISSN 0950-1991

Youngren, K.K.; Nadeau, J.H. \& Matin, A. (2003). Testicular cancer susceptibility in the 129.MOLF-Chr19 mouse strain: additive effects, gene interactions and epigenetic modifications. Hum Mol Genet, Vol.12, No.4, (Februar 2003), pp.389-398, ISSN 09646906

Youngren, K.K.; Coveney, D.; Peng, X.; Bhattacharya, C.; Schmidt, L.S.; Nickerson, M.L.; Lamb, B.T.; Deng, J.M.; Behringer, R.R.; Capel, B.; Rubin, E.M.; Nadeau, J.H. \& Matin, A. (2005). The Ter mutation in the dead end gene causes germ cell loss and testicular germ cell tumours. Nature, Vol.435, No.7040, (May 2005), pp.360-364, ISSN 1476-4687

Zhong, F.; Savage, S.A.; Shkreli, M.; Giri, N.; Jessop, L.; Myers, T.; Chen, R.; Alter, B.P. \& Artandi, S.E. (2011). Disruption of telomerase trafficking by TCAB1 mutation causes dyskeratosis congenita. Genes Dev, Vol.25, No.1, (January 2011), pp.11-16, ISSN 1549-5477

Zhu, R.; Ji, Y.; Xiao, L. \& Matin, A. (2007). Testicular germ cell tumor susceptibility genes from the consomic 129.MOLF-Chr19 mouse strain. Mamm Genome, Vol.18, No.8, (August 2007), pp.584-595, ISSN 0938-8990

Zhu, R.; Heaney, J.; Nadeau, J.H.; Ali, S. \& Matin, A. (2010). Deficiency of splicing factor 1 suppresses the occurrence of testicular germ cell tumors. Cancer Res, Vol.70, No.18, (September 2010), pp.7264-7272, ISSN 1538-7445

Zhu, R.; Iacovino, M.; Mahen, E.; Kyba, M. \& Matin, A. (2011). Transcripts that associate with the RNA binding protein, DEAD-END (DND1), in embryonic stem (ES) cells. BMC Mol Biol, Vol.12, No.1, (August 2011), pp.37, ISSN 1471-2199

Zhu, W.G. \& Otterson, G.A. (2003). The interaction of histone deacetylase inhibitors and DNA methyltransferase inhibitors in the treatment of human cancer cells. Curr Med Chem Anticancer Agents, Vol.3, No.3, (May 2003), pp.187-199, ISSN 1568-0118 


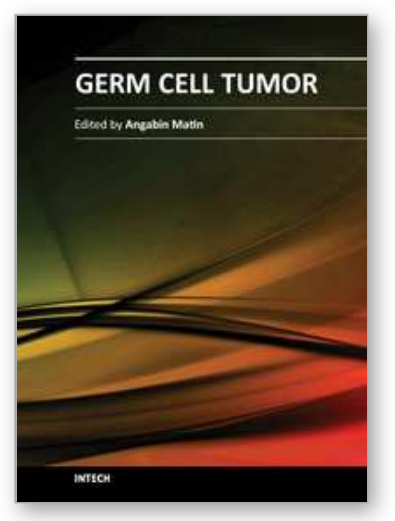

\author{
Germ Cell Tumor \\ Edited by Dr. Angabin Matin
}

ISBN 978-953-51-0456-8

Hard cover, 150 pages

Publisher InTech

Published online 30, March, 2012

Published in print edition March, 2012

The book aims to provide an overview of current knowledge regarding germ cell tumors. It deals with the clinical presentations, treatment modalities, the biology and genetics of germ cell tumors in children and adults. Most chapters are focused on testicular germ cell tumors whose incidence has been increasing in young males. Included are reviews on the pathogenesis, risk factors, diagnosis and treatment regimens applied to precursor, pre-invasive lesions as well as to seminomatous and non-seminomatous germ cell tumors of the testes. In addition, a review is included on the diagnosis and current management options for intracranial germ cell tumors in children. Authors have also contributed articles on the genetics and epigenetics of germ cell tumor development in humans and in the mouse model system. This book will be of interest to scientists, physicians and lay readers wishing to review recent developments in the field of germ cell cancers.

\title{
How to reference
}

In order to correctly reference this scholarly work, feel free to copy and paste the following:

Delphine Carouge and Joseph H. Nadeau (2012). Mouse Models of Testicular Germ Cell Tumors, Germ Cell Tumor, Dr. Angabin Matin (Ed.), ISBN: 978-953-51-0456-8, InTech, Available from: http://www.intechopen.com/books/germ-cell-tumor/mouse-models-of-testicular-germ-cell-tumors

\section{INTECH}

open science | open minds

\section{InTech Europe}

University Campus STeP Ri Slavka Krautzeka 83/A 51000 Rijeka, Croatia Phone: +385 (51) 770447 Fax: +385 (51) 686166 www.intechopen.com

\author{
InTech China \\ Unit 405, Office Block, Hotel Equatorial Shanghai \\ No.65, Yan An Road (West), Shanghai, 200040, China \\ 中国上海市延安西路65号上海国际贵都大饭店办公楼405单元 \\ Phone: +86-21-62489820 \\ Fax: +86-21-62489821
}


(C) 2012 The Author(s). Licensee IntechOpen. This is an open access article distributed under the terms of the Creative Commons Attribution 3.0 License, which permits unrestricted use, distribution, and reproduction in any medium, provided the original work is properly cited. 